\title{
SSCB'nin Dağılma Sürecinden BDT'nin Kurulmasına Kadar Geçen Sürede Karabağ Eksenli Olarak, Nahçıvan, Ermenistan ve Azerbaycan Coğrafyasında Yaşanan Gelişmeler ve Türkiye'nin Tutumu (Ekim 1987- Aralık 1991)* \\ The Developments and Attitude of Turkey in the Geography of Nakhchivan, Azerbaijan and Armenia in Terms of Karabakh Axis, from the Process of Disintegration of the USSR Until the Setting up the CIS (Commonwealth of Independence States) (1987 October-1991 December)
}

\author{
Erdem Karaca**
}

\section{Öz}

Karabağ Ermenileri, Sovyetler Birliği'nin dağılmaya başlamasıyla birlikte önce bağımsızlık, ardından da Ermenistan'a bağlanmak gayretinde bulunmuşlardır. Ermenistan tarafindan desteklenen bu durum, hızlı bir şekilde Azerbaycan'la Ermenistan'l karşı karşıya getirmiştir. Meseleye kayıtsız kalması mümkün olmayan Türkiye ise, ortaya çıkan olumsuzlukların çözümü için yapıcı bir rol oynamaya çalışmiştır.

Çalışmamızda, TBMM Tutanak Dergisi ile Hürriyet Gazetesi temel kaynak olarak kullanılmıştır, Konu başlıkları ise şu şekilde belirlenmiştir: 1.Giriş: Karabağ, 2.SSCB Dağılırken Karabağ Kaynaklı Kaos: Gösteri, Eylem, Çatışma Süreci, 3.Karabağ'n Moskova'ya Bağlanması ve Önlenemeyen Kaos, 4.Türkiye/Azerbaycan/Ermenistan'in Yeni Arayışları, 5.Birliğin Iflası: Kafkaslarda Bağımsızlı Adımları, 6.Azeri-Ermeni Çatışması Sürerken SSCB'nin Lağvı ve Yeni Birlik(BDT), 7.Sonuç ve Değerlendirme.

Anahtar Kelimeler: Karabağ, Sovyetler Birliği(SSCB), Azerbaycan, Ermenistan, Türkiye.

\section{Abstract}

After dispersing of Soviet Union, Karabakh Armenians first made an effort for their freedom then tried to be connected with Armenia. The situation that supported by Armenia caused a huge conflict between Azerbaijan and Armenia. Turkey has sought to play a constructive interference to solve the emergent hitches which is impossible to avoid from this problem.

"The Turkish National Assembly recording journal" and "Hürriyet newspaper" are the main

Makalenin Geliş Tarihi: 30.03.2015 Kabul Tarihi: 18.11.2015

** Yrd.Doç.Dr., Bitlis Eren Üniversitesi, Fen Edebiyat Fakültesi, Tarih Bölümü,

E-posta: erdm.karaca@hotmail.com 
sources in this study. Subject headings are like this: 1. Introduction: Karabakh, 2. Karabakh-Ralated Caos while Soviet Union Separating: Demonstration, Action, Cconflict Process, 3. Karabakh's Bonding to Moscow and Unavoidable Caos, 4. The New Way of Seeking of Turkey, Azerbaijan and Armenia, 5. The Failure of the Union: Liberation Movements in Caucasians, 6. Abolition of Soviet Union and New Consortium (CIS) while Conflict Running on Between Azerbaijan and Armenia, 7. Conlusion and Evaluation.

Keywords: Karabakh, Soviet Union(USSR), Azerbaijan, Armenia, Turkey.

\section{Giriş}

\section{Karabağ}

Kafkaslarda, 16 bin km² lik bir alanı içine alan Karabağ Bölgesi, Azerbaycan'ın Ermenistan ile batı sınırı boyunca uzanmaktadır. ${ }^{1}$ Yapılan çalışmalarda, Karabağ'ın ilk yerleşim birimlerinin Taş Devri'ne kadar uzandığı görülmektedir. ${ }^{2}$ M.Ö. VII-M.Ö. V. yüzyılları arasında Urtekhe/Urtekhina adı ile Urartu Krallığı'nın bir parçası olan Dağlık Karabağ Bölgesi, Ermeni kaynaklarında "Artsakh" olarak anılmıştır. 387 yılında İran(Pers) ve Bizans arasında paylaşılınca, Dağlık Karabağ İran hâkimiyeti altına girmiştir. ${ }^{3}$

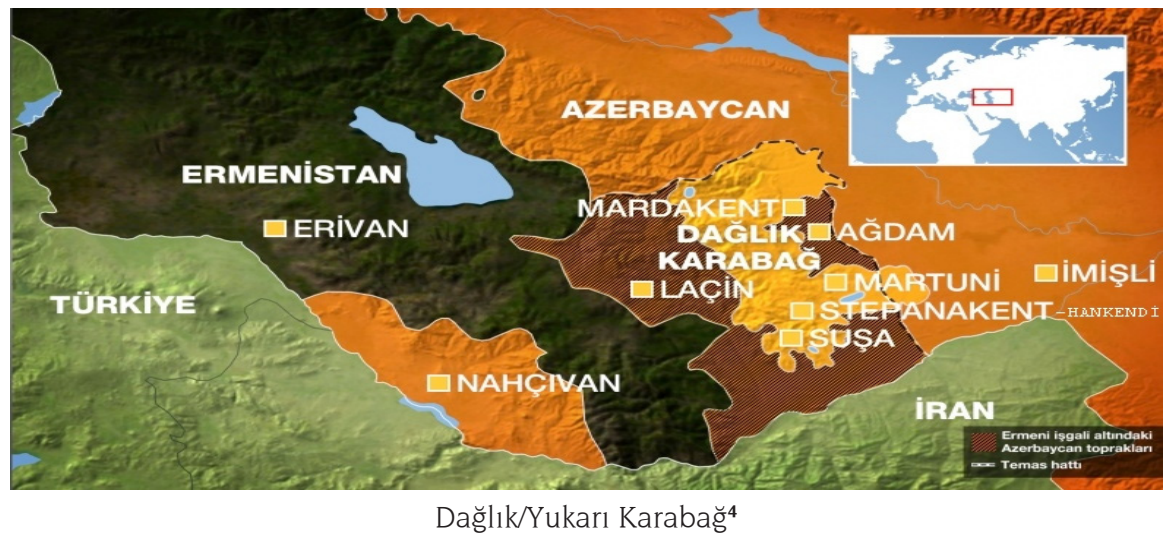

Karabağ'da Ermeni nüfus, Trans-Kafkasya'nın Araplar tarafından tamamen ele geçirilmesinden sonra tarih sahnesine çıkan Haçan Kynazlığı(Prensliği)

1 Günümüzde Karabağ’ın 14 bin km² lik kısmı Ermenistan işgali altında bulunmaktadır. Bkz., Aygün Attar, Karabağ Sorunu Kapsamında Ermeniler ve Ermeni Siyaseti, Atatürk Araştırma Merkezi Yay., Ankara, 2005, 1

2 Ö. Göksel İşyar, Sovyet-Rus Dış Politikaları ve Karabağ Sorunu, ALFA Yay., İstanbul, 2004, s. 80.; Gerger(Gargar), Guger, Uti, Utik, Udin, Otena, Kara, Karalar, Arsak gibi farklı adlarla anılan bölgeye XII-XIII. yüzyıllarda Karabağ adı verilmiştir. Ad, XIV. yüzyılda Fars, Ermeni ve Gürcü yıllıklarında açık bir biçimde kullanılmıştır. Karabağ, Türkçe "kara” ve Farsça "bağ” sözcüklerinden oluşan birleşik bir addır. Bkz., Attar, a.g.e., s. 2-4.

3 Etnik renkliliğini Perslerin hâkimiyetindeyken koruyan bölge, aralarında Ermenilerin de bulunduğu yerel melikler tarafından yönetilmiştir. Bkz., İşyar, a.g.e., s. 111 .

4 http://www.aljazeera.com.tr/dosya/ana-hatlariyla-daglik-karabag-sorunu (Erişim: 08.03.2015) 
SSCB’nin Dağılma Sürecinden BDT’nin Kurulmasına Kadar Geçen Sürede Karabağ Eksenli Olarak, Nahçıvan, Ermenistan ve Azerbaycan Coğrafyasında Yaşanan Gelişmeler ve Türkiye'nin Tutumu (Ekim 1987- Aralık 1991)

döneminde giderek artmıştır. ${ }^{5}$ Farklı görüş ve tartışmalara konu olan Ermenistan coğrafyası, Fransız Historia Üniversitesi tarafından hazırlanan ve 1783'te kralın onayının alınmasından sonra neşredilen "Osmanlı Devleti Tarihi” adlı eserde de yerini almıştır. Eserde, Ermenistan'ın da içerisinde bulunduğu coğrafyanın XIII. yüzyıldan itibaren Türkmenistan olarak adlandırıldığı kaydedilmiştir. XI. yüzyılın ikinci yarısından itibaren Selçuklu, Karakoyunlu, Akkoyunlu, Osmanlı ve Safevi gibi Türk kökenli hanedanlıkların hâkimiyeti altında kalan ve günümüzde merkezi Erivan olarak bilinen Ermenistan coğrafyası dâhilindeki Ermeni nüfus, XIX. yüzyılın ikinci yarısına kadar Müslüman Türk nüfusuna oranla azınlıkta kalmıştır. ${ }^{6}$

1801 'de Rus Çarı I. Aleksandır'ın, Doğu Gürcistan'ı Rusya ile birleştirdiğini açıklaması üzerine, Rusların Revan(Erivan) ve çevresini ele geçirme süreci başlamıştır. Nihayetinde, Rus Çarı I. Nikola, 21 Mart 1828 tarihinde Erivan, Nahçıvan ve Ordubad'ı kapsayan bölgeyi "Ermeni Vilayeti” olarak adlandıran fermanı ilan etmiştir. ${ }^{7}$ Rus işgaliyle beraber, 38.750 Müslüman göçle bölgeden ayrılmıştır. Buna mukabil, Kaçar ve Osmanlı topraklarından 1832'de 45.207, 1840'ta da 57.226 Ermeni bölgeye gelmiş, yerleşmiştir. Rusların teşvikiyle, Kuzey Azerbaycan topraklarında Ermenilerin planlı bir şekilde yerleştirilme uygulaması XIX. yüzyıl süresince ve sonraki dönemlerde devam etmiştir. ${ }^{8}$

Ermeni milli bilincinde, uzun yıllardır beslenen kendi bağımsız devletini kurma fikri, artık yetişmekte olan Ermeni milliyetçiliğinin "Büyük Ermenistan" siyasi hedefi etrafında şekillenmekteydi. Hedefin fikir sahiplerine göre "Büyük Ermenistan", Anadolu'da ve Rus Çarlığı'nın Azerbaycan/Gürcistan topraklarında kurulmalıydı. Ermeni, Hınçak(1887) ve Taşnaksutyun(1890) partileri/örgütleri, işe koyularak hızla silahlanmışlardır. İsyanlara kalkışarak, Avrupalıların dikkatini Ermeni mili mücadelesine çekecek çatışma ortamını yaratmak istemişlerdir. I. Dünya Savaşı'nda Ermenilere büyük destek veren Rusya, Ermenilerin Özerklik ve kendi devletlerini oluşturma arzusunu gerçekleştirecek katkılarda bulunmuştur. Ne var ki, 1917 yılı başında Rusya'da ortaya çıkan siyasi gelişmeler, tüm Kafkasya'da ve I. Dünya Savaşı'nda büyük değişikliklere yol açtığı

5 Tarihsel belgelere ve araştırmalara bakıldığında Karabağ Bölgesi, Ermenilerin ileri sürdüğü gibi, Ermeni Zakaryan Kynazlığı'na bağlı bir alt bölge durumuna hiçbir zaman düşmemiştir. Bkz., İşyar, a.g.e., s. 109.

6 Oktay Kızılkaya, “Günümüz Ermenistan Coğrafyasında Türk Nüfusunun Tarihi Süreçteki Durumu", Yeni Türkiye, Ermeni Meselesi Özel Sayısı IV, Yıl: 20, Sayı: 63(Eylül-Aralık 2014), Yeni Türkiye Stratejik Araştırma Merkezi Yay., Ankara, 2014, s. 2600.

7 Yavuz Aslan, "Rus İstilasından Sovyet Ermenistanı'na Erivan(Revan) Vilayeti'nin Demografik Yapısı (1827-1922)", Yeni Türkiye, Ermeni Meselesi Özel Sayısı IV, Yıl: 20, Sayı: 63(Eylül-Aralık 2014), Yeni Türkiye Stratejik Araştırma Merkezi Yay., Ankara, 2014, s. 2611-2613.

8 Nigar Gözelova, “Rusya İmparatorluğu'nun Dış Politikası ve XIX. Yüzyılın Başlarında İrevan Hanlığı'nda Etnodemografik Durumun Değişmesi”, Yeni Türkiye, Ermeni Meselesi Özel Sayısı IV, Yıl: 20, Sayı: 63(Eylül-Aralık 2014), Yeni Türkiye Stratejik Araştırma Merkezi Yay., Ankara, 2014, s. 2624-2625. 
gibi, Ermeni Meselesi'ni de geri plana itmiştir. ${ }^{9}$ Ancak yine de, Mayıs 1918'de Erivan Vilayeti topraklarında bir Ararat Cumhuriyeti oluşturuldu. Azerbaycan Cumhuriyeti, 29 Mayıs 1918'den geçerli olmak üzere Erivan şehrini Ararat Cumhuriyetine vermiştir. Osmanlı Devleti ile Ararat Cumhuriyeti arasında Batum'da imzalanan antlaşmayla Ararat Cumhuriyeti'nin toprakları 10 bin km² olarak belirlenmiştir. ${ }^{10}$

1918 yılı sonlarında Kafkaslarda, 18 aylık bir “ittilaf” hâkimiyeti gerçekleşmiştir. İtilafçı İngiltere, Karabağ ve Zengezur bölgeleri konusunda yaşanan tartışmaların halledilmesi amacıyla, Ermenistan ile Azerbaycan arasında arabuluculuk yapmış ve 1919 yılı Ocak ayında adı geçen bölgelerin kesin olarak Azerbaycan sınırları içerisinde kalması şartıyla özel bir valiliğe dönüştürülmesini sağlamıştır. Nahçıvan'ın Ermenistan'a verilmesini engelleyen Türkiye ise, bölgenin özerk bir statü ile Azerbaycan'ın himayesi altına alınmasını 13 Ekim 1921 tarihinde imzalanan Kars Antlaşması ile Sovyet Rusya, Azerbaycan, Gürcistan ve Ermenistan'a tasdik ettirmiştir. Sovyet Rusya'yı burada öne çıkaran hadise, Rusların Güney Kafkasya'da İtilaf Devletleri'nin hâkimiyetine 27 Nisan 1920'de son vermiş olmasıydı. Dağlık Karabağ'ın statüsünün de bu yeni duruma göre şekilleneceği günler pek uzak görünmüyordu ve 1923 yılına gelindiğinde bölgeye, Azerbaycan Sovyet Sosyalist Cumhuriyeti içerisinde özerk bir statü verilmiştir. ${ }^{11}$

\section{SSCB Dağılırken Karabağ Kaynaklı Kaos: Gösteri, Eylem, Çatışma Süreci}

10 Mart 1948 tarihinde Sovyet yönetimi tarafından göçlerle ilgili konuları içine alan bir karar yayınlanmıştır. İkircikli bir tutum içeren karara göre, Azeriler eski göç yasasına binaen yurtlarından çıkarılırken, Ermeniler ise, yeni yasa doğrultusunda yurtlarına yerleştirilmeye başlanmıştır. 1961 yılında ülke dışında yaşayan Ermenilerin Ermenistan'a göçünü kabul eden bir yasa tasarısı da onaylanmıştır.

1985'te, Komünist Parti olağan kurultayında, SSCB Genel Sekreteri Mihayıl Sergeyeviç Gorbaçov'un, Sovyetler Birliği'nin değişen politikasını ve takip edeceği yolu "Şeffaflık ve Yeniden Yapılandırma" olarak açıklaması, yeni bir takım kıpırdanmalara işaret etmiştir. ${ }^{12}$ Pek çok Sovyetolog, söz konusu du-

9 Solmaz Rüstemova Tohidi, "Birinci Dünya Savaşı Yıllarında Ermeniler Tarafından Azerbaycan'ın Erivan, Zengezur ve Karabağ Eyaletlerinde Müslüman Nüfusunun Soykırımı", Yeni Türkiye, Ermeni Meselesi Özel Sayısı IV, Yıl: 20, Sayı: 63(Eylül-Aralık 2014), Yeni Türkiye Stratejik Araştırma Merkezi Yay., Ankara, 2014, s. 2653-2663.

10 İlgar Vahitoğlu Nifteliyev, "1918-1920 Yıllarında Ermenilerin Erivan Bölgesinde Azerbaycan Türklerine Karşı Yaptıkları Soykırım ve Azerbaycan'la İlgili İddiaları”, Yeni Türkiye, Ermeni Meselesi Özel Sayısı IV, Yıl: 20, Sayı: 63(Eylül-Aralık 2014), Yeni Türkiye Stratejik Araştırma Merkezi Yay., Ankara, 2014, s. 2628-2629.

11 Dağlık Karabağ bölgesinde Ermeni özerk yönetiminin oluşması, Karabağ topraklarının parçalanmasına ve ileriki yıllarda Ermenistan'a, bu topraklar üzerinde yeniden hak iddia etmek için hukuki, siyasi ve stratejik bir zemin hazırlamıştır. Bkz., Nifteliyev, a.g.m., s. 2633, 2638. 
SSCB’nin Dağılma Sürecinden BDT’nin Kurulmasına Kadar Geçen Sürede Karabağ Eksenli Olarak, Nahçıvan, Ermenistan ve Azerbaycan Coğrafyasında Yaşanan Gelişmeler ve Türkiye'nin Tutumu (Ekim 1987- Aralık 1991)

rumu, otuz-kırk yıldır yazmaktaydı. "Prestroika", "Glasnost" kelimeleri dünya literatürüne girdiğinde ve herkesin az çok bu konulara ilgi duymaya başladığı dönemlerde, bu konudaki otoriteler; "Bu iş ciddidir. Bu, bir Rus ruleti değildir. [...] bir oyun değildir. [...] bazılarının dediği gibi, NATO'yu zayıflatmak için betahsis yapılan bir hareket değildir.|... aklınızı başınıza alın; bu iş bambaşka bir iştir. Çaresizdir, orası bunu yapacaktır. Gorbaçov olmasa da başka birisi yapacaktır; çünkü tarihi süreç ve bunun silindiri böyle gelmektedir."13 şeklinde katiyen duyurmuşlardır.

SSCB'de, Azeriler açısından yeni bir zorlu bir dönemece girildiği muhakkaktı. İlk ciddi belirti olarak, Azerbaycan KGB Şefi ve aynı zamanda Başbakan Birinci Yardımcısı olan Azeri asıllı Haydar Aliyev, Gorbaçov tarafından ülkenin en üst siyasi organı olan Politbüro'daki görevinden alınmıştır. ${ }^{14}$

Aliyev'in etkisizleştirildiği süreçte, Gorbaçov'un Başdanışmanı Ermeni asıllı Abel Aganbegyan, Azerbaycan'a bağlı Karabağ ve Nahçıvan'ın, nüfus çoğunluğunun Ermenilere ait olduğu gerekçesiyle Ermenistan'a bağlanması gerektiğini Gorbaçov'a söylemiş ve "halledilecek" cevabını almıştır. ABD'de yayımlanan Ermeni dergilerinin neşrettiği bilgilere göre de, Ekim 1987'de Erivan'da, yaklaşık bin kişinin katıldığı bir gösteriye güvenlik güçlerinin müdahalesi söz konusu olmuştur. Ayrıca, Ekim ayında Karabağ'ın Çardaklı Köyü'nde gösteri yapan Ermenilerle Azeri Türkleri arasında çatışma çıkmıştır. Türkiye, bütün bu gelişmeleri, Ermenilerin, Türkiye'den toprak istemekliğinin bir modeli olarak Sovyetlerde ete, kemiğe bürünmesi şeklinde telakki edilmiştir. ${ }^{15}$ Konuyla ilgili olarak, nasıl bir dış politika takip edileceğine değinen Başbakan Turgut Özal, Sovyetler Birliği ve diğer sosyalist devletlerle, egemenlik, bağımsızlık, hak eşitliği, toprak bütünlüğüne saygı ve iç işlerine karışmama ilkeleri çerçevesinde dostluk ve iyi komşuluk ilişkilerini geliştirmeyi, özellikle ekonomik ve ticari alandaki işbirliğini artırmayı amaçladıklarını belirtmiştir. ${ }^{16}$

13 ANAP Kayseri Milletvekili Recep Orhan Ergun'un konuşmasından. Bkz., TBMM Tutanak Dergisi, Dönem: 18, Yasama Yılı: 4, Cilt: 37, Birleşim: 52, Oturum: 1, 20.12.1989, s. 210, 212 ; Görülen o ki; 1980'li yıllarda Perestroika(yeniden yapılanma), Glasnost(açıklık-saydamlık) ve Novoe Mysshlenia(yeni düşünce) gibi yeni yaklaşımlar Sovyetler Birliği'nde liberal reformlar sürecini başlatmıştır. Bu durum, eş zamanlı olarak Dağlık Karabağ Meselesi'ni, Azerbaycan ve Ermenistan arasında bir siyasi anlaşmazlık noktasına çıkarmıştır. Bkz., Dağlık Karabă̆ Sorunu/Dar Alanda Büyük Oyun, Ed.: Turgut Demirtepe, USAK Avrasya Araştırmaları Merkezi Raporu, No: 11-07, 2011, s. 5.

14 Daha önce Grigory Romanov, Victor Grişin, Nikolay Tihonov ve Dinmuhammed Kunaev Politbüro'dan istifa etmişlerdir. Sağlık sorunları nedeniyle görevden ayrıldı̆̆ını belirten Aliyev, 1982 Kasım'ında Politbüro üyeliğine yükselmiştir. Haziran 1987'den itibaren Politbüro'ya uğramadığı için, hakkında, ağır hasta olduğu ya da "Gorbaçov tarafından saf dışı edildiği" yolunda söylentiler çıkmıştır. Brejnev'ci olarak bilinen 64 yaşındaki Aliyev, Gorbaçov'un iktidara geldiği 1985 Mart'ından itibaren Politbüro'dan istifa etmek durumunda kalan beşinci kişi olmuştur. Aliyev'in ayrılması ile Gorbaçov'un, Politbüro'daki gücü daha da artmıştır. Bkz., "Gorbaçev Tırpanı", Hürriyet, 22 Ekim 1987, s. 10.

15 “Ermeni İştahı Kabarıyor...", Hürriyet, 25 Aralık 1987, s. 1, 8.

16 TBMM Tutanak Dergisi, Dönem: 18, Yasama Yıl1: 1, Cilt: 1, Birleşim: 3, Oturum: 1, 25.12.1987,

Akademik Bakış 117 Cilt 9 Sayı 17 Kış 2015 
Bu arada, 8 Aralık 1987 günü, ABD ile SSCB arasında imzalanmış olan antlaşmayla, her iki ülkenin karada konuşlandırılmış orta menzilli füzelerin dünyadan tamamen tasfiyesini öngörmeleri hadisesi ise, Cumhurbaşkanı K. Evren tarafından memnuniyet verici bir gelişme olarak dile getirilmiştir. ${ }^{17}$ Böylece, “Soğuk Savaş Dönemi”nden kalma endişe, tehdit ve algıları normalleştirirken, Kafkasya'da durum pek iç açıcı değildi. Hareketliliklerini artıran Ermeniler, çevreyi kirletecek bir lastik fabrikasının kuruluşunu protesto amacıyla gösteriler başlatmışlardır. Gösteriler, bir anda Karabağ ve Nahçıvan özerk bölgelerinin Ermenistan sınırlarına dâhil edilmesi eylemlerine dönüşmüştür. Karabağ Bölgesi Komünist Partisi Birinci Sekreteri Boris Kevorkov'un "görevinde yetersiz kaldığı” gerekçesiyle azledilerek, yerine Ermeni asıllı Pogosyan'ın getirildiğini açıklamıştır. Olayların yatışması için televizyondan açıklama yapan Ermenistan Komünist Partisi Lideri Karen Demirciyan, Ermenileri sükûnete davet etmiştir. ${ }^{18}$ Ermeni-Azeri Radyo-Televizyonu'ndan çağrıda bulunan Gorbaçov; Lenin'in uluslarla ilgili siyasi prensipleri çerçevesinde, mantıklı bir yaklaşımla sorunun çözümlenmesi gerektiğini, Karabağ ve Nahçıvan'daki karışıklıktan aşırı unsurların sorumlu olduğunu söylemiş, sabırlı ve soğukkanlı davranılması gerektiğini belirtmiştir. ${ }^{19}$ Ancak, 1 milyonu aşkın kişi ile Erivan'da meydanları dolduran Ermeniler, Gorbaçov'un, Ermenilerin isteklerinin adil bir çözüme kavuşturulacağı konusunda söz vermesi üzerine, gösterileri bir ay süreyle ertelemişlerdir. ${ }^{20}$

Azeri yazar Velayet Kuliyev, The New York Times'de yayımlanan demecinde; Sovyet Ermenileri'nin güçlü bağlantıları sayesinde dünyayı etkilediklerini, Azerilere yönelttikleri katliam suçlamalarının asılsız, olayları ilk başlatanların Ermeniler olduğunu belirtmiş, son zamanlarda Ermeni milliyetçilerinin yine Büyük Ermenistan düşü kurmaya başladıklarını, bu bağlamda Azerbaycan, Gürcistan, Türkiye ve İran'ın bazı bölgelerini ilhak etme yönündeki istediklerine değinmiştir. ${ }^{21}$ Ermenilerin Karabağ'1 istemesini müteakip, ABD Kongresi ve

17 TBMM Tutanak Dergisi, D: 18, YY: 1, C: 1, B: 1, O: 1, 14.12.1987, s. 8.; Dişişleri Bakanı Mesut Yılmaz da, antlaşmayla, tarihte ilk defa belirli bir kategori nükleer silahın kaldırıldı̆̆ına ve Türkiye üzerindeki nükleer tehdidin bir ölçüde azalacağının ihtimal dâhilinde olduğuna işaret etmiştir. Bkz., TBMM Tutanak Dergisi, D: 18, YY: 1, C: 2, B: 16, O: 2, 02.02.1988, s. 78.

18 Olaylar, ilk olarak, Sovyet yetkililerin Erivan'a 15 km uzaklıktaki Abovyan'a yeni bir sentetik lastik fabrikası açılmasını protestoyla başlamıştır. Ermeniler, 1917 Devrimi'nden önce Karabağ ve Nahçıvan'da oturanların \%95'nin Ermeni olduğunu ileri sürmüşlerdir. Bkz., “Ermeniler Gorbaçev'in Başını Ağrıtıyor”, Hürriyet, 25 Şubat 1988, s. 3, 16.

19 Çağrısına ve bölgeye gönderilen ağır donanımlı polis birliklerinin varlığına rağmen, olayların bastırılmasında ilk etapta beklenen etki elde edilememiştir. Bkz., "Kremlin'de, Ermenistan Şaşkınlığı", Hürriyet, 27 Şubat 1988, s. 3, 14.

20 "Gorbaçev Boyun Eğdi", Hürriyet, 29 Şubat 1988, s. 10.

21 Sovyet Televizyonu, resmi verilere göre 32 kişinin öldüğü Sumgait kentindeki olaylara(28 Şubat) dair kısa görüntüler paylaşmıştır. Ayrıca, Karabağ'daki etnik çatışmaları içeren kaçak/kurgusal(!) bir video hazırlanmıştır. 24-26 Şubat tarihlerinde bir Ermeni gazetecinin çektiği iki videokasette, on binlerce kişinin yaptı̆̆ı gösteriler ve yaralanan Ermenilerin 
SSCB’nin Dağılma Sürecinden BDT’nin Kurulmasına Kadar Geçen Sürede Karabağ Eksenli Olarak, Nahçıvan, Ermenistan ve Azerbaycan Coğrafyasında Yaşanan Gelişmeler ve Türkiye'nin Tutumu (Ekim 1987- Aralık 1991)

ABD’deki Ermenilerin kurduğu Ermeni Aydınlar Birliği, haksızken, Ermenilerin haklı olduğunu yaymaya ve kabul ettirmeye çalışmışlardır. Gorbaçov, Ermeniler lehinde olmak üzere, Avrupalılar ve ABD Kongresi tarafından bir yönlendirilmeyle, sıkıştırmayla karşı karşıya kalmıştır. ${ }^{22}$

Ermenistan'da yaşananlar, "Bir açıdan bakınca, [...] Gorbaçev'in izlemeye başladığı 'açıklık' politikasının [...] çeşitli uluslarda yarattı̆̆ı dalgalanmaların yenisidir. [...] son birkaç yıl içinde[...] güvenlik güçleriyle halkı karşı karşıya getiren olaylar çıkmış, Kırım Tatarları, Kremlin meydanında gösteriler yapmışlardır. Ancak Ermenistan olaylarının, [...] bir başkalığı vardır. Kazakistan olayları, [...] Kunayev'in görevinden ve Politbüro'dan uzaklaştırılması üzerine [...] yandaşları tarafından çıkarılmıştı. [...] Kırım Tatarları'nın isteği, 'Nazi Almanya'sıyla işbirliği yapmak' suçlamasıyla uzaklaştırıldıkları yurtlarına geri dönmekti. [...] Ermeniler, gösterilerini, [...] cumhuriyetlerini genişletmek, [...] Azerbaycan'dan toprak almak için düzenliyorlar. [...] Sovyetler Birliği'nin iç haritasını [...] yeni baştan düzenlemek [...] peşindedirler. [...] Bu olay, [...] militanlara arka çıkan Kremlin'in gözünü açmalıdır. 'Büyük Ermenistan' hayali bu militanların asıl amacıdır ve bu [...] Sovyetler Birliğgi'nin ‘ulusal bütünlügü̈' ve 'iç barışı' için de büyük tehlikedir. [...]”. ${ }^{23}$ SSCB ise, yıllardır, Ermeni tehdidi konusunda Türkiye'ye, "Siz, bize değil, diğer dostlarınıza bakın; neler yapıyorlar, neleri hoş görüyorlar" demekteydiler. ${ }^{24}$

Nihayet, Karabağ Meselesi'ni Özel oturumda gündeme alan Sovyet Yüksek Prezidyumu'nda, Karabă̆ Bölgesi'nin Ermenistan'a bağlanmasını reddedilmiş, Azeri ve Ermeni liderlere, bölgedeki etnik unsurların haklarını korumaları ve düzenin sağlanması için gerekli önlemleri almaları çağrısında bulunulmuştur. ${ }^{25}$ Karabağ'ın iadesi talebiyle girişilen protesto gösterilerine bir süreyle ara veren moratoryum 26 Mart'ta sona ererken, Yüksek Sovyet

kaldırıldığı hastanelerden görüntülere yer verilmiştir. Videoda, hastanelerdeki Ermeniler, Azerbaycanlılar tarafından nasıl saldırıya uğradıklarını anlatmış ve ayrıca, Azeriler tarafından tamamen yağmalanmış ve ateşe verilmiş bir binadan dışarıya atılmış eşyalar gösterilmiştir. Bkz., "Büyük Ermenistan Hayali”, Hürriyet, 12 Mart 1988, s. 12.

22 Ermenistan ve Azerbaycan haritalarına bakıldı̆̆ında, Karabağ’ın Ermenistan'a neden bağlanılmak istendiği açıktı. Anadolu'nun, Hazar Denizi'ne uzantısı durumunda olan Azerbaycan'ın, bir defa parçalanıp bölünmesi yetmezmiş gibi, tekrar bölünüp parçalanmaSı amaçlanmaktaydı. Karabağ'dan sonra sıra Nahçıvan'a gelecekti. Bu durum Ermenilerin gizlemediği bir hakikatti. Bkz., ANAP Kars Milletvekili Sabri Aras'ın konuşmasından. TBMM Tutanak Dergisi, D: 18, YY: 1, C: 5, B: 39, O: 1, 22.03.1988, s. 10-11.

23 Haluk Ülmen, "Bir Musibet, Bin Nasihatten İyidir", Hürriyet, 27 Şubat 1988, s. 3, 14.

24 Yalnız, Bulgaristan'daki Türklere reva görülen insanlık dışı muamele karşısında yaptıkları gibi, Ermenistan konusunda da Türkiye'ye sıcak bakmadıkları ortadaydı. Bkz., DYP Hatay Milletvekili Mustafa Murat Sökmenoğlu'nun konuşmasından. TBMM Tutanak Dergisi, D: 18, YY: 2, C: 21, B: 49, O: 1, 21.12.1988, s. 442, 446.

25 Sovyetlerde yayınlanan haftalık Literaturnaya Gazeta Dergisi, Karabağ'daki olayların Amerika Merkezi Haber Alma Örgütü CIA tarafından kışkırtıldığını öne sürmüştür. Bkz., "Ermenilere Ret”, Hürriyet, 24 Mart 1988, s. 8. 
Prezidyumu'nun Karabağ’a yönelik almış olduğu karar, bir ölü şehir sessizliği içinde protesto edilmiştir. ${ }^{26}$

Ermenilerin protestoları sürerken, Bakü'de de on binleri bulan Azeri Türkü'nün "Ermenilere ölüm” sloganıyla sokaklara dökülmüş ve Sovyet yönetiminden, Karabağ'ın Ermenistan'a bağlanması yönündeki isteklere boyun eğmemesi istenmiştir. ${ }^{27}$ Sovyet Yönetimi'nin kesinlikle karşı olduğunu belirtmesine rağmen, Ermenistan Komünist Partisi Lideri Suren Arutunyan, Sovyet Anayasası'ndaki "Ulusların kendi geleceğini belirleme hakkında sahip olduğu" maddesine dayanarak, Karabağ'ın Ermenistan'a bağlanması konusunda açık bir tavır sergilemiştir. Buna karşın, Bakü'de göstericilere hitaben konuşan Azerbaycan Komünist Partisi Lideri Abdul Vezirov ise, Karabağ Bölgesini Ermenistan'a asla vermeyeceklerini söylemiş ve Ermeni isteklerinin anayasaya aykırı olduğunu ileri sürmüştür. ${ }^{28}$ Ayrıca, "Yetmiş yıllık deneyime dayanarak; ekonomi, kültür, din ve dil ile ilgili en karmaşık sorunların, Özerklik çerçevesinde çözülebileceğini" belirtmiştir. Bu yapıcı açıklamaya rağmen, Ermenistan Sovyet Cumhuriyeti Yüksek Şurası, oybirliğiyle, Karabağ'ın Ermenistan'a bağlanmasını kararlaştırmıştır. ${ }^{29}$

Tüm girişimlere rağmen, Karabağ'da durum kötüye gitmiştir. Sovyet birliklerinin Karabağ'a gönderilmesine rağmen tehlike ortadan kalkmamıştır. Buna ilaveten, Ermenistan'la Azerbaycan arasından patlak veren "etnik kavga”, Gürcistan ve diğer Sovyet cumhuriyetlerinde de kaygıya yol açmıştır. ${ }^{30}$ Bunu gören Gorbaçov, cumhuriyet sınırlarının kesinlikle değiştirilemeyeceğini belirtmiş, Ermenileri ise memnun olmamıştır. Erivan'da yayılmakta olan grevi örgütleyen komite bir bildiri yayınlayarak, özellikle, Karabağ yönetiminin herhangi bir başka cumhuriyete devrini istemiştir. ${ }^{31}$ Buna karşın, Moskova,

26 Erivan'da ve Karabağ’ın merkezi Stepanakert'te(Hankendi) hiçbir Ermeni evinden çıkmayarak protestoya iştirak etmiştir. Bkz., "Erivan Meydan Okudu", Hürriyet, 27 Mart 1988, s. 11.; Komünist Partisi resmi yayın organı Pravda, Ermeni ayaklanmasının otomotiv ve taşımacılık sektöründe yol açtığı zararın 2.4 milyon dolara ulaştığını ve Azerileri zorladığını bildirmiştir. Kaliforniya eyaletinin Ermeni asıllı valisi George Dökmeciyan, Gorbaçov'a bir mektup yazarak, Karabağ özerk bölgesiyle ilgili kararı eleştirmiş ve Ermenilerin "tarihi bir adaletsizliğe" maruz bırakıldığını öne sürmüştür. Bkz., "Ermeniler Kremlin'e Aldırmıyor”, Hürriyet, 30 Mart 1988, s. 8. İngiliz BBC Radyosu, uzun geçmişi olan tarihsel Türk-Ermeni düşmanlığının, son aylarda SSCB sınırları içerisinde yoğunlaştığını belirtmiş, her iki halkın uzlaşmaz tutumunun, Moskova'yı zor durumda bıraktığını kaydetmiştir. Bkz., "Azerbaycan'da Milliyetçi Patlama”, Hürriyet, 13 Haziran 1988, s. 10.

28 “Karabağ Ermenistan’a Bağlanacak...”, Hürriyet, 15 Haziran 1988, s. 10.

29 “Ermenistan'dan Karabağ'ı İlhak Kararı”, Hürriyet, 16 Haziran 1988, s. 10.

30 “Sovyetlerde Alarm”, Hürriyet, 25 Haziran 1988, s. 10.; Sürekli gösteri yapan Ermeniler, Ermeni Havaalanı'nda Kızıl Ordu birlikleriyle çatışmaya girmişlerdir. Olayda, 3 kişi ölmüş, 36 kişi de yaralanmıştır. Bkz., “Ermenistan İsyanda”, Hürriyet, 07 Temmuz 1988, s. 8.

31 Ermeni istekleri: “1- 28 Şubat’ta Azerbaycan'ın Sumgait kentindeki Ermeni karşıtı olaylara karıştıkları gerekçesiyle tutuklanan kişiler Azerbaycan mahkemelerinde değil, Sovyet Yüksek Mahkemesi'nde yargılansın. 2- Karabağ'daki askeri kuşatma kaldırılsın. 3- Masis kentinde 40 fabrika işçisi kadının zehirlenmesi ve bölgesel anlaşmazlıkla ilgili bilgi verilsin." Bkz., “Ermenilerden Geri Adım”, Hürriyet, 09 Temmuz 1988, s. 11. 
Erivan'a sevk ettiği takviye birliklerle kilit noktaları tutmuş, ancak, başkentte gerginlik devam etmiştir. ${ }^{32}$ Bu esnada, Karabağ Parlamentosu, Azerbaycan'dan ayrılıp Ermenistan'a bağlanma kararı almıştır. ${ }^{33}$ Karabağ'da çok sayıda silah ve mühimmat bulunması, ayrılma kararının silahlı çatışmaya dönüşebileceği yönündeki endişeleri oldukça artırmıştır. ${ }^{34}$

Ermeniler, taktik nedenlerle grevlere son verme kararı alırken, durum karşısında bir açıklama yapan Azerbaycan Cumhurbaşkanı Yardımcısı Naim Fatalyev ise, "Karabağ bizimdir. Bizde kalacaktır. [...] alınan kararlar [...] Sovyet Anayasası'nın 78. Maddesine tamamen terstir ve geçersizdir. Sovyetler Birliği sınırları içinde yaşayan Ermenilerin \%10'u Azerbaycan'da, \%1 1'i Gürcistan'da, \%6'sı Rusya Federasyonu'nda bulunuyor. [...] Yani, SSCB'deki Ermenilerin \%36'sı Ermenistan'ın dışında bulunuyor. Bunların her biri, bulundukları yerde toplanıp, 'Biz burada çoğunluktayız' diyerek o cumhuriyetin sınırlarıyla ilgili kararlar alabilir mi? Alırlar denilirse, bu, nereye varır? [...] Azerbaycan, egemen bir cumhuriyettir. Bu cumhuriyette yaşayan 7 milyon nüfusun 2/3'ü, yani 5.5 milyonu, yapılacak referandumda, oyuyla açık rızasını belirtmedikçe bizim toprağımız olan Karabağ’ı bizden kimse alamaz. [...|"35 demiş ve böylece mücadele edileceğini ilan etmiştir.

Meseleyi görüşmek üzere toplanan Sovyet Yüksek Prezidyumu, Azeri ve Ermeni temsilcilerinin tezlerini dinledikten sonra, oybirliği ile aldığı kararla, Karabağ'ın Azerbaycan Cumhuriyeti'nin bir parçası olduğunu benimsemiştir. ${ }^{36}$ Ancak, Azerilerle Ermeniler arasında çıkan olaylar üzerine, Ermenistan karışmıştır. Erivan'a gönderilen askeri birlikler kenti denetim altına almıştır. Karabağ'ın merkezi Stepanakert'te ise, sokağa çıkma yasağı ilan edilmiştir. ${ }^{37}$ Ermenistan' da kontrolü sağlayan ${ }^{38}$ Gorbaçov, "Kremlin'de darbe" diye nitelenen son girişimiyle de, reformları destekleyen kimseleri yönetimde kilit mevkilere getirmiştir. ${ }^{39}$

Sovyet yetkililerinin Karabağ olaylarını durdurmak için harcadıkları gayretlere rağmen çatışmalar devam etmiştir. Bakü'de can güvenliğini devriye gezen tanklar sağlarken, Nahçıvan'dan 500 kadar Ermeni'nin tahliyesi yoluna gidilmiştir. Erivan'da ise, yüz binlerce insan yine meydanlara inmiştir. ${ }^{40}$

32 "Ermenistan Patlamaya Hazır", Hürriyet, 11 Temmuz 1988, s. 8.

33 "Karabağ'da Ölüm Andı", Hürriyet, 13 Temmuz 1988, s. 10.

34 "Karabağ Silahlandı", Hürriyet, 15 Temmuz 1988, s. 10.

35 "Karabağ'1 Kimse Alamaz", Hürriyet, 18 Temmuz 1988, s. 10.

36 "Ermenilere -Kesin- HAYIR", Hürriyet, 19 Temmuz 1988, s. 10.; Karabağ’da kamu düzeni ve iş disiplinini sağlamak üzere harekete geçen Moskova, Sovyet ve Azeri savcılar vasıtasıyla, grevde bulunan fabrikaların yöneticileri hakkında soruşturma başlatılmıştır. Alınan önlemlere rağmen grev ve eylemler durdurulamamıştır. Bkz., "Moskova'dan Ermenilere Baskı", Hürriyet, 24 Temmuz 1988, s. 10.

37 "Ermenistan Bela Oldu", Hürriyet, 23 Eylül 1988, s. 10.

38 "Moskova Duruma Hâkim", Hürriyet, 27 Eylül 1988, s. 10.

39 “Kremlin'de Reform Bayramı”, Hürriyet, 02 Ekim 1988, s. 10.

40 "Sovyetler'de Kâbus", Hürriyet, 25 Kasım 1988, s. 9. 


\section{Karabağ'ın Moskova'ya Bağlanması ve Önlenemeyen Kaos}

Karabağ'ı gündeminden düşürmeyen Ermenistan, 7 Aralık 1988 günü yaşanan 7.2 büyüklüğündeki Gümrü (Spinak) Depremi ile sarsılmıştır. Sarsıntı, 20 bin kişinin hayatına mal olmuştur. ${ }^{41}$ Türk Kızılayı, siyasetten uzak insancıl bir yaklaşımla, afetin hemen ardından, Ermenistan'daki olumsuz çevrelerin çıkardığı tüm zorluklara rağmen, yapabileceği tüm yardımları yapmıştır. Ancak yardımlar sürecinde Başbakan Turgut Özal'ın tavrı muhalefetçe sert bir biçimde eleştirilmiştir. ${ }^{42}$

Depremle birlikte, Sovyet topraklarında bağımsızlık girişimleri, çalkantılar, çatışma ve gösteriler sürerken, yeni yıl mesajı yayımlayan Gorbaçov, reform düşmanlarının direnişi dolayısıyla işlerin iyi gitmediğine ve 1988'de zorlukların arttığına değinmiştir. Ancak, ABD ile yürütülen karşılıklı ilişkilerden memnun olduğunu ve ABD Başkanı R. Reagan gibi 1989'dan umutlu olduğunu belirtmiştir. ${ }^{43}$

Bu arada, Karabağ meselesi konusunda çalışmalarını sürdüren Kremlin Yönetimi, Ermenilerin bir yıldır sürdürdüğü gösterilere boyun eğerek, Azerbaycan'a bağlı bu özerk bölgeyi Moskova'ya bağlamıştır. Karar, Azerilerin tepkisine yol açacak mahiyette idi. ${ }^{44}$ Bölgedeki durumu gergin ve karmaşık olarak niteleyen TASS, Stepanakert'teki Azerilerin çalıştıkları iş yerlerine gitmesine izin verilmediğini, Şuşa'da da Ermenilerin korkudan işe gidemediğini belirtmiştir. Karabağ'ın imarı için 1989'da ayrılan 153 milyon doların sadece 4 milyon dolarının Azerilerin oturduğu bölgeler için harcandığını bildirmiştir. ${ }^{45}$ Haksızlık karşısında, Karabağ'ın Azerbaycan'a iade edilmesi için baskı yapan Halk Cephesi marifetiyle harekete geçen Azerbaycan Parlamentosu, "payla-

41 http://tr.wikipedia.org/wiki/1988_Spitak_Depremi (Erişim: 19.03.2015)

42 DYP Grubu adına görüşlerini belirten Hatay Milletvekili Mustafa Murat Sökmenoğlu, konuyu ele alarak şunları söylemiştir: “[...] Sayın Başbakan, uluslararası bir görüntü yaratmak için girişimlerinde zaman zaman ölçüyü kaçırmakta, hem kendisini, hem ülkeyi zor durumlara düşürmektedir. [...] yardım konusunu uluslararası bir propaganda vesilesi olarak kullanmak istemektedir. Üstelik, [...] (Medya patronu) Maxvel, Sayın Başbakanı Davos'tan arayıp, ‘Depremden harap olan Ermenistan'a [...] yardım yapın. Şu sıralarda böyle bir jest yaparsanız, Amerikan kamuoyunda olumlu tepkiler olur. Ermeni soykırımı iddialarına karşı bu insancıl tavır alkış toplar' diye telkinde bulunup, hem Sayın Başbakan'ın [...] hem de Türkiye'nin Sovyetler Birliği karşısında sıkıntıya girmesine sebep olmuştur. 20 helikopterlik yardım, Sovyet Ermenistanı içinde, Türklere karşı yerleşmiş olumsuz duygular nedeniyle reddedilmiştir. [...]". Bkz., TBMM Tutanak Dergisi, D: 18, YY: 2, C: 21, B: 49, O: 1, 21.12.1988, S. 442, 445-446.; SHP İçel Milletvekili M. İstemihan Talay da, Başbakan'ı eleştirerek, insani amaçlarla, Ermenistan'daki depreme gönderilmesi gereken yardımın, kaba bir propagandaya dönüştüğü için, Sovyetler tarafından geri çevrildiğini belirtmiştir. Bkz., Tutanak Dergisi, D: 18, YY: 2, C: 21, B: 49, O: 1, 21.12.1988, s. 475, 477.

43 "Sistem Çalışmıyor", Hürriyet, 02 Ocak 1989, s. 8.

44 "Ermenilere Ödün”, Hürriyet, 16 Ocak 1989, s. 10.

45 "Karabă̆ Yine Ayakta”, Hürriyet, 11 Mayıs 1989, s. 10.; Ve çok geçmeden Karabağ'da şiddetli çatışmalar patlak vermiştir. Bkz., "Karabağ Yine Alev Alev”, Hürriyet, 15 Ağustos 1989, s. 10. 
SSCB’nin Dağılma Sürecinden BDT’nin Kurulmasına Kadar Geçen Sürede Karabağ Eksenli Olarak, Nahçıvan, Ermenistan ve Azerbaycan Coğrafyasında Yaşanan Gelişmeler ve Türkiye'nin Tutumu (Ekim 1987- Aralık 1991)

Şılamayan" bölgeyi Ocak ayından itibaren doğrudan Moskova'ya bağlı olarak yöneten komitenin feshedilmesi talebiyle Yüksek Sovyet'e başvurma kararı almıştır. ${ }^{46}$

Karşılıklı hamlelerin ardı arkası kesilmemiştir. Sözde Ermeni Soykırımı Tasarısı'nın, ABD Kongresi'nden geçme ihtimalinin artması üzerine, Ermeniler Türkiye'ye yönelik toprak taleplerini yeniden gündeme getirmek için kolları sıvamışlardır. Ermenistan Parlamentosu, Moskova Antlaşması'nın yasal açıdan geçerliliğini incelemek üzere bir komisyon oluşturma kararı almıştır. ${ }^{47} 16$ Mart 1921'de, imzalanan Moskova Antlaşması'nın 3. maddesine göre; "Bağlı taraflar, antlaşmanın 1 (c) ekinde belirlenen sınır içindeki Nahçıvan kesiminin koruyuculuk hakkını üçüncü bir devlete hiçbir zaman bırakmamak koşuluyla, Azerbaycan koruyuculuğunda özerk bir bölge oluşturulması konusunda anlaşmışlardır." ${ }^{\prime 4}$

Karabağ Meselesi, Türkiye'den bağımsız gelişebilecek gibi görünmüyordu. Yüzlerce kişi 12 km'lik Türkiye-Nahçıvan sınırına yürüyerek sınır taşlarını devirmişlerdir. Türkiye'ye bir ziyaret gerçekleştiren Azerbaycan Başbakanı Niyazi Muttalibov, Nahçıvan'daki gösteriler için; "Bu yeni tefekkürün [...] bir sonucu. Bu problemi de çözeceğiz. Şimdi [...] heyecan var." şeklinde yorumlamıştır. ${ }^{49}$ Buna karşın, isteklerinde sınır tanımayan Ermeniler, Ermenistan Radyosu yayınlarında, Ağrı'yı kastederek, "Ararat'sız Ermenistan düşünülemez" demekten dahi geri durmamışlardır. Karabağ hadiseleri sebebiyle, Ermenistan'dan Azerbaycan'a kaçmak zorunda kalanların sayısı ise, 200 bini aşmıştır. ${ }^{50}$

46 “Top Kremlin'de”, Hürriyet, 17 Eylül 1989, s. 10.; Azerbaycan'daki direniş örgütleri: 1-Ulusal Halk Cephesi; En geniş halk kitlesine sahipti. Tam bağımsız Azerbaycan Cumhuriyeti'nin oluşmasını istemekteydi. Komşu ülkelerle eşitliğe dayalı barışçı ilişkiler kurmak niyetindeydi. Gösterilerinde, ay-yıldızlı, yeşil, mavi, kırmızı Azerbaycan bayrağını kullanmaktaydı. 2-Vatan Cephesi: Bir Kültür ve Dayanışma Derneği niteliği taşımaktaydı. Azerbaycan'ın tüm dünyada tanımasına çalışmaktaydı. Çeşitli ülkelerde temsilcilikler açmıştır. İslâmi bir yapılanma düşünmemiştir. Lideri Azerbaycan Parlamentosu milletvekili Elçi Bey'di. 3-Kurtuluş Cephesi: Halk Cephesi'nden ayrılanlar kurmuştur. Daha sert çözümlerden yanaydı. Olayların ilk gününden itibaren savaş ilan etmiştir. Hedef, tam bağımsızlıktı. 4-Tövbe: Dini temele dayalı idiler. Siyaset ilgi alanları arasında bulunmuyordu. Kur'an kursları açmak, camilerde ezan okunmasını sağlamak asıl mücadele konularıydı. Bkz., Hürriyet, 25 Ocak 1990, s. 10.

47 "Ermeniler Toprak İstiyor", Hürriyet, 10 Ekim 1989, s. 12.; DYP Samsun Milletvekili İrfan Demiralp'in konuşmasında belirttiği üzere ; Turgut Özal'a göre, ABD açısından “Ermeni Karar Tasarısı" bir atımlık barut değildi. Bkz., Tutanak Dergisi, D: 18, YY: 4, C: 37, B: 54, O: 1, 22.12.1989, s. 492, 496.

4813 Ekim 1921 tarihli Kars Antlaşması'nın 5. Maddesi ile de, “Türkiye Hükümeti ile Ermenistan ve Azerbaycan Hükümetleri işbu anlaşmanın 3 sayılı ekinde belirtilen sınırlar içinde olmak üzere Nahçıvan Bölgesi'nde Azerbaycan'ın koruyuculuğunda özerk bir ülke oluşturulması konusunda anlaşmışlardır." hükmü kabul edilmiştir. ANAP Kars Milletvekili Sabri Aras'ın konuşmasından. Bkz., TBMM Tutanak Dergisi, D: 18, YY: 1, C: 5, B: 39, O: 1, 22.03.1988, s. 11.

49 "Nahçıvan Halkı Türkiye Sınırına Yürüdü", Hürriyet, 06 Kasım 1989, s. 10.

50 ANAP Kars Milletvekili Sabri Aras'ın konuşmasından. Bkz., TBMM Tutanak Dergisi, D: 18, YY: 3, C: 32, B: 18, O: 1, 18.10.1989, s. 529-530. 
Hadiselerin bir diğer takipçisi olan Avrupa Parlamentosu, Karabağ Meselesi'nin Ermenilerin arzusu doğrultusunda çözülmesini istemiştir. ${ }^{51}$ Türkiye açısından ise, o güne kadar, yakın komşuları içerisinde an az sorunun bulunduğu ülke Sovyetler Birliği idi. Ne var ki, Sovyetler Birliği ile iktisadi ilişkilerinin devamlı olarak geliştiği günlerde, ne Gorbaçov, ne de Dişişleri Bakanı Şevardnadze, Türkiye'ye adım dahi atmamışlardır. Fırsattan yararlanan Sovyet Ermenistanı, Gümrü Antlaşması'nı tek taraflı olarak feshettiğini açıklamış ve Türkiye'den toprak istemiştir. Moskova buna tepki dahi göstermemiştir. ${ }^{52}$

Batılı gözlemcilere gelince; "Gerek İran, gerek Sovyet Azerilerinin büyük çoğunluğunun, kendilerini önce Türk saydıklarına ve Ankara'yla yaklaşmayı umut ettiklerine" dikkat çekmişlerdir. Fransız Libération Gazetesi yazarlarından ve Sovyetler Birliği uzmanı Alfred Adler, “|... Güneyde Pers İslâmcılığının, kuzeyde de Sovyet sosyalizminin iflası, bölgeyi çalkantılara sürükleyecek milliyetçi bir hareketin doğuşu için uygun koşullar yaratıyor" değerlendirmesinde bulunmuştur. ${ }^{53}$ Çok geçmeden Sovyet Azerileri, İran'daki soydaşlarıyla daha yakın ilişkiler kurmak için sınırın açılmasını istemiş ve Sovyet-İran sınırındaki tesisleri yıkmışlardır. İran resmi haber ajansı İRNA, Tahran Times Gazetesi'nde yayımlanan bir makaleye yer vererek, "Kremlin, Azerbaycan halkına baskı yapmaktan kaçınmalıdır. Eğer konuya yumuşak ve mantıklı şekilde yaklaşılırsa, iki komşu arasındaki kültürel ilişkiler zenginleşecektir" açıklamasında bulunmuştur. $^{54}$

Amerika Ulusal İstihbarat Konseyi eski Başkan Yardımcısı Graham Fuller, Los Angeles Times Gazetesi'ndeki makalesinde, Türkiye-İran ilişkilerinin kırılganlığına dikkat çekerek şöyle bir değerlendirmede bulunmuştur: “Moskova ve Tahran'ın, Azeriler konusunda işbirliği yapmaları beklenebilir. Hıristiyan olan Ermeniler ve Gürcüler de güçlü bir Müslüman Azerbaycan'ı önlemek için [...] ortak hareket edeceklerdir. Bütün bunlardan en çok etkilenecek ülke ise Türkiye olacaktır. Türkiye'ye ufak bir kara koridoru ile bağlı Azerbaycan da Türkiye'den destek beklemektedir. [...] desteklemek ise Türkiye ile İran'1 birbirine düşürecektir. Siyasi ve dil bakımından Ankara'ya bakan Azeriler, din olarak [...] İran'daki Azerilere kendilerini yakın kabul etmektedirler. [...] bunlar İran ile Türkiye arasında yeni bir ihtilaf konusu olacaktır." ${ }^{55}$ Bu asada, Sovyetler Birliği ile iyi komşuluk ilişkilerini ve geliş gidişleri geliştirmek isteyen Türkiye, 60 yıl sonra Sarp Sınır Kapısı'nın(Artvin-Gürcistan) açılışını yaparak önemli bir eksikliği gidermeye çalışmıştır. ${ }^{56}$

51 DYP Kahramanmaraş Milletvekili Atilla İmamoğlu'nun konuşmasından. Bkz., TBMM Tutanak Dergisi, D: 18, YY: 4, C: 37, B: 52, O: 1, 20.12.1989, s. 221, 223.

52 SHP Manisa Milletvekili M. Erdoğan Yetenç'in konuşmasından. Bkz., TBMM Tutanak Dergisi, D: 18, YY: 4, C: 37, B: 54, O: 1, 22.12.1989, s. 468, 476.

53 "Azerilerin Umudu Ankara”, Hürriyet, 06 Ocak 1990, s. 10.

54 "Sovyet Azerileri Ayaklandı", Hürriyet, 07 Ocak 1990, s. 10.

55 "Azeriler Yüzünden, Türkiye ile İran Kapışacak", Hürriyet, 11 Ocak 1990, s. 10.

56 SHP Artvin Milletvekili Ayhan Arifağaoğlu'nun konuşmasından. Bkz., TBMM Tutanak Dergisi, 
SSCB’nin Dağılma Sürecinden BDT’nin Kurulmasına Kadar Geçen Sürede Karabağ Eksenli Olarak, Nahçıvan, Ermenistan ve Azerbaycan Coğrafyasında Yaşanan Gelişmeler ve Türkiye'nin Tutumu (Ekim 1987- Aralık 1991)

Ara ara memnuniyet veren durumlar olsa da, Kafkaslarda tansiyon her geçen gün daha da artmaktaydı. Azeriler, Karabağ konusundaki kararlılıklarını Bakü'de Halk Cephesi öncülüğünde düzenledikleri dev bir mitingle göstermek istemişlerdir. Ancak, ölümcül olaylar yaşanmıştır. Halk Cephesi, olayların provokasyon olduğunu öne sürerken, Ermeni-Azeri çatışmasının sürdüğü Karabağ'da olağanüstü durum ilan edilmiştir. ${ }^{57}$ İşi sıkı tutan Kremlin, ErmeniAzeri çatışmasını, "Sovyet iktidarını ve anayasal düzeni silahlı eylem yoluyla yıkma girişimi" olarak değerlendirmiş ve bölgeye güç göndermiştir. ${ }^{58}$ Bakü'de olağanüstü durumun kaldırılması ve seferberlik ilanının geri alınmasını isteyen Azeriler, Komünist Partisi binasını kuşatmış ve Parti Genel Sekreteri'nin istifasına neden olmuştur. Ancak Rus tankları, büyük bir sertlikle, halkın üzerine ateş açmıştır ${ }^{59}$

Olayların vahim bir noktaya geldiği anda Türkiye'den gelen açıklamalar ve yaklaşımlar tartışma konusu olmuştur. Cumhurbaşkanı Turgut Özal'ın ABD'de Azerilerin daha çok İran'ı ilgilendirdiği yönündeki açıklamasına karşılık, son Bakanlar Kurulu'nda bütün bakanların, Azerbaycan için Türkiye'nin arabuluculuk yapmasını önerdikleri bilgisi gündeme düşmüştür. Sovyetler Birliği'nin içişlerine müdahale anlamına geleceği gerekçesiyle teklife sıcak bakmayan Dışişleri Bakanı M. Yılmaz, bakanların ısrarı üzerine, dışişlerinin bu konuyu detaylı olarak inceleyeceğini ve uygun bir prosedür bulmaya çalışılacağını söylemiş60 “Gelişmeleri, ilke itibarıyla, Sovyetler Birliği'nin içişleri çerçevesinde değerlendirmekteyiz. [...] bu tutumumuzun, iyi ilişkiler içinde olmaya önem verdiğimiz Sovyetler Birliği'nin sınırlarımızın hemen ötesindeki bir bölgesinde, yakın kültürel bağlarımız olan Azeri halkını müessif gelişmelere karşı, Türk-Sovyet ilişkilerinin her alanda daha da geliştirilebilmesi vadedici bir zemin hazırlayan yenilenme ve demokratikleşme sürecini olumsuz şekilde etkileyebilecek gelişmelere karşı ilgisiz kalacağımız anlamına gelmediği [...] aşikârdır." ${ }^{\prime 1}$ demiştir.

Azerilerin sesini duyurmak için, uzunca bir bildiri yayınlayan Azerbaycan Vatan Cemiyeti, "Sovyet ve batı basını tek yanlı yayınlarında Azerileri 'kan içici,

\section{D: 18, YY: 4, C: 39, B: 64, O: 1, 16.01.1990, s. 90-92.}

57 “Azerbaycan Kan Gölüne Döndü”, Hürriyet, 15 Ocak 1990, s. 10.

5811 bin kişiden oluşan Kızıl Ordu, KGB ve donanma sevk edilmiştir. Bkz., "Ve Kremlin Müdahale Etti", Hürriyet, 17 Ocak 1990, s. 10.; Önlemler konusunda Türkiye haberdar edilmiştir. Türkiye, Sovyet makamlarının, iyi komşuluk ve dostluk ilişkilerinin gereğine uyacağına inandığını belirtmiştir. Bkz., "Ankara, Olaylardan Kaygılı", Hürriyet, 17 Ocak 1990, s. 10

59 "Kızılordu Azerilere Ateş Açtı", Hürriyet, 20 Ocak 1990, s. 10.

60 "Azerbaycan. Bakanlar Kurulu'nu Karıştırdı", Hürriyet 20 Ocak 1990, s. 10.; SHP Tokat Milletvekili Kâzım Özev, Azerbaycan'da cereyan eden olaylar karşısında Cumhurbaşkanı Turgut Özal'ı görüş ve tutumu dolayısıyla ağır bir biçimde eleştirmiştir. Devlet Bakanı Mehmet Yazar ise, cevaben şunları söylemiştir; “ [...] anladığım kadarıyla, Sayın Cumhurbaşkanı'nın o ifadesi, maksadını aşmış bir ifadedir. Nitekim, kendileri bir süre sonra düzeltmişlerdir, tavzih etmişlerdir." Bkz., TBMM Tutanak Dergisi, D: 18, YY: 4, C: 40, B: 68, O: 1, 24.01.1990, s. 15-16.

Akademik Bakış 125 Cilt 9 Sayı 17 Kış 2015 
vahşi' kılığında, Ermenileri ise 'mazlum' olarak gösteriyor. Dünya kamuoyunu yanıltıyorlar. Bizi boğmaya çalışıyorlar" demiş ${ }^{62}$ ve Nahçıvan Yüksek Sovyeti de, bağımsızlığını ilan ederek, İran ve Birleşmiş Milletler'den(BM) yardım istemiştir. ${ }^{63}$ Ayrıca, Kızıl Ordu'nun Bakü'den çekilmesi için Sovyet Yönetimi'ne 48 saat süre tanıyan Azerbaycan Parlamentosu, Bakü'deki olağanüstü hal uygulamasını da geçersiz ilan ettiğini açıklamıştır. ${ }^{64}$ Kızıl Ordu'nun Azerbaycan müdahalesinin, daha fazla kan dökülmemesi için bir zorunluluk olduğunu savunan Sovyet Dişişleri Bakanı Edvard Şevardnadze, kargaşanın uluslararası istikrarsızlığa yol açabileceğini söylemiştir. ${ }^{65}$ Yaşananları değerlendiren Kars Milletvekili Sabri Aras ise, şu noktalara işaret etmiştir; Dağlık Karabağ olaylarının başladığı günlerde, ABD, soykırım iddiasını gündeme getirmiştir. Avrupa Parlamentosu, Ermenilere yardım için karar almıştır. Bayan Mitterand, Ermenileri desteklemek için gönüllüler ordusu oluşturmak çabası içerisine girmiştir. Bütün dünyaya, açıklık politikası ile sempatik görünmeye çalışan Gorbaçov, Kızıl Ordu'yu Azerbaycan'ın üzerine yürütmüş, Ermeni ve Kızıl Ordu işbirliğiyle Bakü ve Nahçıvan kana boyanmıştır. ${ }^{66}$

62 "Bizi Boğuyorlar", Hürriyet, 21 Ocak 1990, s. 10.

63 "Nahçıvan, Bağımsızlık İlan Etti”, Hürriyet, 21 Ocak 1990, s. 10.; Nahçıvan'ın bağımsızlığını ilan etmesinden bir süre önce, Azerbaycan Halk Cephesi egemenlik ilan etmiş ve bu egemenlik girişimi Azerbaycan Komünist Partisi ve Yüksek Sovyeti tarafından kabul edilmiştir. DYP Bursa Milletvekili Beytullah Mahmet Gazioğlu'nun konuşmasından. Bkz., TBMM Tutanak Dergisi, D: 18, YY: 4, C: 37, B: 54, O: 1, 22.12.1989, s. 500, 503.

64 "Azerbaycan'dan Ültimatom", Hürriyet, 23 Ocak 1990, s. 10; İngiliz The Independent Gazetesi'nin yorumu; “Sovyetler Birliği'nde etnik kökenli sorunların hemen hemen tümünün temelinde ekonomik sömürü yatıyor. Elverişli iklim koşulları nedeniyle oldukça önemli bir tarımsal potansiyele sahip olan Azerbaycan Cumhuriyeti, bunu değerlendirmek bir yana [...] Ermenistan'dan yaklaşık 200 bin mültecinin gelmesiyle daha da büyük boyutlara ulaşan bir işsizlik sıkıntısıyla karşı karşıya. [...] din unsurunun Azeri ayaklanmasında bugüne kadar 'esas itici güç' olmadığı, ancak Moskova daha fazla bastırdığı takdirde, olabileceği [...]". Bkz., "Azerbaycan Sömürgeciliğe İsyan Etti”, Hürriyet, 23 Ocak 1990, s. 10.

"Moskova'dan Azerbaycan Savunması", Hürriyet, 30 Ocak 1990, s. 11.; Ermeni çeteleri Azerbaycan-Ermenistan sınırındaki üç Azeri köyüne baskın düzenleyerek birçok evi ateşe vermişlerdir. Bkz., "Azerbaycan'da Ermeni Vahşeti: 5 Ölü”, Hürriyet, 25 Mart 1990, s. 12.

66 TBMM Tutanak Dergisi, D: 18, YY: 4, C: 39, B: 67, O: 1, 23.01.1990, s. 258-259.; Aras, ayrıca şunlar1 söylemiştir; "Azerbaycan hadiselerinin temelinde ne yatmaktadır? [... SSCB'nin diğer cumhuriyetlerinde bu hadiseler yok muydu? Litvanya'da, Ukrayna'da, diğger Baltık cumhuriyetlerinde de vardı [...] onlar Gorbaçov'un açılılık politikasına güvenmişlerdi [...] Türk milletinin, Gorbaçov'a aşırı samimiyeti olmuştu. [...] barıştan yana, insan haklarından yana olduğunu kabul etmiştik. Ne yazık ki, Litvanya'daki hadiselerde [...] Litvanya'ya kadar giden, oradaki insanlarla sokak ortalarında sohbet eden Gorbaçov, Azerbaycan-Ermenistan konusunda kendi vatandaşlarına zulmetmiştir. Mazlumdan değil, zalimden yana olmuştur. [...] Moskova'nın Ankara Büyükelçisi Çernişev, 'Karabağ olaylarında Azerbaycanlılar haklıdır' diyor. [...] Mademki Azerbaycanlılar Karabağ hadisesinde haklıdır, mademki [...] Türkleri sindirmeye çalışan Ermenilerdir, neden Kızıl Ordu Ermenistan'a değil de Azerbaycan'a girdi? [...] bunun tek sebebi vardı; o da, Azerbaycan'da yaşayan soydaşlarımızın Türk ve Müslüman olmasıydı. [...]”. Bkz., TBMM Tutanak Dergisi, D: 18, YY: 4, C: 40, B: 71, O: 1, 31.01.1990, s. 197-198. 
SSCB’nin Dağılma Sürecinden BDT’nin Kurulmasına Kadar Geçen Sürede Karabağ Eksenli Olarak, Nahçıvan, Ermenistan ve Azerbaycan Coğrafyasında Yaşanan Gelişmeler ve Türkiye'nin Tutumu (Ekim 1987- Aralık 1991)

\section{Türkiye/Azerbaycan/Ermenistan'ın Yeni Arayışları}

Kardeşliğin bir tezahürü olarak Azerbaycanlılar, hem Halk Cephesi hem Azerbaycan Hükümeti olarak Türkiye ile iktisadi ve kültürel ilişkileri geliştirmek arzusundaydı. Türk-Sovyet dostluğuna ve bölgede barışın, statükonun korunmasına büyük katkı sağlayacak olan, Türkiye ile Sovyetlerdeki Türk kökenli halkaların ekonomik ve kültürel ilişkilerin geliştirilmesine özel önem vermek zorunluluğu vard1 ${ }^{67}$ Azerbaycan'daki gelişmeler nedeniyle harekete geçen Türk Hükümeti, Ankara'da ilk kez bir asker-sivil zirvesi yapmıştır. Zirveye, Başbakan Yıldırım Akbulut, Dışişleri Bakanı Mesut Yılmaz ve Genelkurmay Başkanı Nacip Torumtay katılmıştır. Varılan noktanın endişe ve üzüntüyü artırdığı, Sovyet Güvenlik Kuvvetleri'nin tutumu nedeniyle, gelişmelerin kitlesel bir insan hakları sorunu haline dönüşmekte olduğu üzerinde durulmuştur. ${ }^{68}$

Türkiye'deki gündemi yakından takip eden Sovyet resmi haber ajansı TASS, TBMM'de Azerbaycan olayları hakkında yapılan tartışmaların, SSCB'nin içişlerine müdahale anlamı taşıdığını ileri sürerek, bunun "Türk-Sovyet ilişkilerinde istikrara hizmet etmeyeceğini" bildirmiştir. ${ }^{69}$ Başbakan Yıldırım Akbulut ise, Azerbaycan konusunda hükümete haksız eleştiriler yöneltildiğini belirtmiş ve “[...] olaylarda, tarihi husumetlerin etkisi bulunmakla birlikte, gelişmelerin bugün ulaşmış olduğu aşamanın ve gözlediğimiz tırmanmanın temelinde, sosyo-ekonomik sorunların yanı sıra [...] Yukarı Karabă̆ Bölgesi'ne yönelik Ermeni toprak taleplerinin yattığı gerçektir. [...] Sovyet yetkililerce [...] Ermenilerin toprak taleplerinin yersizliğine işaret olunmuştur. Sayın Gorbaçov [...] soruna bulunacak çözümün Azerbaycan'ın toprak bütünlüğüne halel gereğini vurgulamış; Ottawa'da Dışişleri Bakanımız ile görüşen Sayın Şevardnadze, |... bölgede en küçük bir sınır değişikliğine dahi müsamaha edilmeyeceğini [...] ifade etmiştir. Ne var ki, Ermenilerin, bir anlamda kiracısı oldukları Yukarı Karabağ Bölgesi'nin tapusu üzerinde hak iddia etmeleriyle başlayan olaylar, maalesef bir ay kadar önce [...] Azeri kanının döküldüğü bir noktaya erişmiştir."70 demekle yetinmiştir.

67 Bakü'de konsolosluk açılması, Nahçıvan kapısının tamamlanması, Azerbaycan'a kredi açılması gibi hususların hızla yerine getirilmesi gerekmekteydi. DYP Bursa Milletvekili Beytullah Mahmet Gazioğlu'nun konuşmasından. Bkz., TBMM Tutanak Dergisi, D: 18, YY: 4, C: 37, B: 54, O: 1, 22.12.1989, s. 505.

68 “Ankara'da Azeriler İçin Kritik Toplantı”, Hürriyet, 24 Ocak 1990, s. 14.

69 "TASS...", Hürriyet, 25 Ocak 1990, s. 10.

70 TBMM Tutanak Dergisi, D: 18, YY: 4, C: 41, B: 80, O: 1, 21.02.1990, s. 245-253.; Dişişleri Ali Bozer, Türkiye'nin Batı ile ilişkilerine değinerek şu hususlara dikkat çekmiştir; "Ermeni tasarısı dolayısıyla, Amerikan Senatosu'nda cereyan eden olay nedeniyle hepimiz fevkalade üzüldük; fakat sonuç olarak, alınan karar, bizi önemi ölçüde tatmin etmiştir. Bunun dışında, NATO, askeri mahiyetini değiştirmekte, siyasi bir nitelik kazanmaktadır. |...] Türkiye'nin, bunlardan dolayı, mütenebbih olarak, dış politikasını, Batıdan başka istikamete değiştirmesi veya bugüne kadar izlediği çok yönlü politikadan vazgeçmesi söz konusu değildir. [...]”. Bkz., TBMM Tutanak Dergisi, D: 18, YY: 4, C: 43, B: 100, O: 1, 10.04.1990, s. 252.; Ayrıca, Bozer, Senatör Dole'un, Amerikan Senatosu'ndan geçirmeye çalıştığı haksız soykırım iddiasını içeren tasarının, Hükümetin yoğun çabaları ve ABD Senatosu üyelerinden önemli bir bölümünün basiretli davranışlarıyla önlendiğini belirtmiş, 20 Nisan 1990 tarihinde yazılı açılama

Akademik Bakış 127 Cilt 9 Sayı 17 Kış 2015 
Öte taraftan, Bakü'de çatışmalar devam ederken, Nahçıvan-Ermenistan sınırında Azerilerle Ermeniler arasında ateşkes ilan edilmiştir. Kanlı olayların ardından görevinden alınan Azerbaycan Komünist Partisi lideri Abdülrahman Vezirov partiden atılırken, liderliğe Başbakan Ayaz Muttalibov getirilmiştir. ${ }^{71}$ Olumsuz gelişmelere rağmen, Nahçıvan Özerk Cumhuriyeti Hükümeti'yle Ermenistan Hükümeti arasında kurulan diyalog sonucunda, Nahçıvan ile Azerbaycan arasındaki, Ermeni topraklarından geçen demiryolu hattının güvenliğ̈inin sağlanması ve Ermenistan ile Nahçıvan sınırı boyunca 5 km'lik bir tampon bölge oluşturulması ve bölgede kimsenin silah taşımaması için önlem alınması kararlaştırılmıştır. ${ }^{72}$ Nahçıvan iyiye giderken, Dağlık Karabağ'da ise, Ermeni militanları Azerilere saldırmışlardır. Duruma binaen, Azerbaycan halkının infialini haklı bulduğunu söyleyen Gorbaçov, ilk kez Azerilere hak vermiştir. ${ }^{73}$ Gorbaçov'u pek de ciddiye almayan ve Sovyetlerden ayrılmak için ha-

yapan Başkan Bush'un, '24 Nisan tarihinde, Ermenilerin 75 yıl önce uğradığı katliamın anılışına katıldığını ifade etmiş', böylece Ermenilerin beklediği soykırım sözünü kullanmadığına değinmiştir. Bkz., TBMM Tutanak Dergisi, D: 18, YY: 4, C: 46, B: 126, O: 1, 12.08.1990, s. 437438.; Uzun süren tartışmalardan sonra, DYP Sakarya Milletvekili Mehmet Gölhan'ın, ABD Başkanı Bush'un 24 Nisan tarihli açıklamasına karşı tepkisi ve Türkiye'nin etkisiz çıkışına yönelik açılaması şöyledir; “[...] Mr. Bush, [... '1915-1923 yılları arasında Osmanlılar 1 milyon Ermeni'yi katletmiştir' [... ve 'Ey Ermeniler, bu acı gününüzde sizinle beraberiz' diyor. Sonra, işin ciddiyetini anlıyor ve hemen Beyaz Saray'a giderek bir açılama yapıyor: 'Biz, bunu bugünkü Türklere demiyoruz.' [...] 'Osmanlılara diyoruz. Biz Türkiye ile dostuz' diyor ve Senatör Byrd, bu sözler karşısında dayanamayıp görüşünü açıklıyor.' Bana deseniz ki, Mr. Byrd, biz seni seviyoruz. Sen iyi adamsın; ama senin deden at hırsızı idi. O zaman ben at hırsızının torunu olmaz mıyım? O halde sizin, bana iyi adamsın demenizin anlamı nedir? [...] Türklere diyorsunuz ki, Biz sizi seviyoruz [...] dostunuz; ama dedeleriniz katildi.' [... Çankaya'dan verilen yanıt $[\ldots]$ çok ilginç, [...] Ne diyor Sayın Cumhurbaşkanı? 'Evet, böyle bir beyanat iyi olmamıştır [...] ama Mr. Bush, bunu bir iç politikası bakımından söylemiştir.' [...] Bu yanıt, kamuoyunda gerçekten yankılar uyandırıyor. [...]". Bkz., TBMM Tutanak Dergisi, D: 18, YY: 5, C: 52, B: 46, O: 1, 12.12.1990, s. S. 277, 292.

71 Halk Cephesi ise, Muttalibov'un parti liderliğinden hoşnut olmamıştır. Bkz., "Azerbaycan 'Ya Zafer, ya Ölüm' Diyor", Hürriyet, 26 Ocak 1990, s. 10.

72 "Ermeni-Azeri Sorununda Umut Işı̆̆ı", Hürriyet, 04 Nisan 1990, s. 12.; Mayıs ayında yaşanan bir olaya dikkat çeken Sabri Aras, şu önemli değerlendirmelerde bulunmuştur; “[...] Türkiye ne zaman iyi bir yere gelse, ekonomik durumunu düzeltse, siyasal durumunu yola koysa, hemen, bizi istemeyen komşularımız ve sözde dostlarımız Avrupalılar üzerimize yürümektedir. 02 Mayıs 1990 günü, şimdiye kadar Ermenilerin oyununa gelmeyen Almanya da aynı oyuna gelmiştir. Bir idari mahkemenin [...] aldı̆̆ı karar var: 1980 yılından sonra Türkiye'de Ermenilere eziyet edildiği ve bu yüzden Almanya'da bulunan Ermenilerin ilticalarının kabul edilmesi, orada askerlik çağına gelmiş, asker kaçağı gençlerin, eziyet yapılacağı gerekçesiyle Türkiye'ye gönderilmemesi karar bağlanmıştır. [...] Biz, Ermenilere düşman değiliz.; geçmişte onlarla aynı araziyi paylaştık [...] savaştık [...] barıştık. Bugün de dün de, Ermeniler, Osmanlı Devleti'nde en büyük makamları işgal ettiler, milletvekilliği yaptılar ve muhtelif bakanlıklarda müsteşarlık görevi aldılar [...] Amerika'nın ve Avrupa'nın yaptığı, Ermenilere dostluk değildir, [...] onları kışkırtmaktır, bölgenin istikrarını bozmaktır, Trans-Kafkasya'yı kan gölü haline getirmektir. [...]". Bkz., TBMM Tutanak Dergisi, D: 18, YY: 4, C: 44, B: 110, O: 1, 08.05.1990, s. 345-346.

73 "Gorbaçov: Azerilerin Sabrı Taşıyor", Hürriyet, 13 Temmuz 1990, s. 10.; Bu arada, Rusya Federasyonu halkına karşı sorumluluklarını ve çok partili sisteme inancı nedeniyle sadece Komünist Parti'nin talimatlarına uymayacağını belirterek, partiden istifa eden radikal 
SSCB’nin Dağılma Sürecinden BDT’nin Kurulmasına Kadar Geçen Sürede Karabağ Eksenli Olarak, Nahçıvan, Ermenistan ve Azerbaycan Coğrafyasında Yaşanan Gelişmeler ve Türkiye'nin Tutumu (Ekim 1987- Aralık 1991)

rekete geçen Ermeniler, bağımsızlık bildirisini, Ermenistan Parlamentosu'nda da kabul etmişlerdir. ${ }^{74}$

Ermenistan ve Azerbaycan'ın teşebbüsleri birbiri ardına gelmekteydi. Azerbaycan Sosyalist Halk Cumhuriyeti Başbakanı Hasan Hasanov, Türkiye ile Azerbaycan arasında direkt devlet ilişkisi kurulmasını teklif ederek, Nahçıvan sınır kapısıyla Aras Nehri-Arapaçay üzerine bir sınır kapısı kurulmasına dair projenin 1991 yılı sonuna kadar gerçekleştirilmesini istemiştir. ${ }^{75}$ Azerbaycan'ın girişiminden sonra, Ermenistan Cumhuriyeti'nin yeni yetkilileri de, sanki ön almak istercesine, Türkiye ile Ermenistan arasındaki tarihe dayanan sorunlara yaklaşımlarında bazı değişiklikler meydana geldiğini belirterek, ticari ilişkiler aracılığıyla, uzlaşmaya giden yolun bulunmasını istemişlerdir. ${ }^{76}$

Sovyetler Birliğgi'ndeki çözülmeye uygun bir hızla hareket edilmediğine dikkat çeken Mahmut Öztürk(DYP Niğde Milletvekili), doğru bir perspektifle şu Önerilerde bulunmuştur; “[...] bugün Sovyet Sosyalist Cumhuriyetleri'nde 10'u aşkın İslâm-Türk cumhuriyeti vardı. Devlet Planlama Teşkilatı [...] gözünü, [...] elini buraya açmalı. [...] mutlaka açmalı. Onlarla ilgili bir birimi vakit geçmeden kurmalıdır. Şayet biz bunları kurmazsak, bir başkası mutlaka kuruyor. İran kuruyor, Arabistan kuruyor ve Batı devletleri kuruyor. DPT, bu konuda geç kalmamalıdır."77

Sovyet Cumhuriyetleri'nde gelişmeler, Türkiye'nin yeni yerlerde konsolosluk ve misyonlar açmasını da gerektirmekteydi. Bakü'de bir konsolos-

Demokratik Platform fraksiyonu lideri Boris Yeltsin, Vladimir Şostakovsky ve diğerlerinin de istifasına yol açarak, Komünist Parti'ye en büyük darbeyi vurmuştur. Bkz., "Yeltsin, Komünist Parti'den İstifa Etti", Hürriyet, 13 Temmuz 1990, s. 10.

74 Bildiride, Ermenistan Sovyet Sosyalist Cumhuriyeti olan devlet adını Ermenistan Cumhuriyeti şeklinde değiştirmişlerdir. Ayrıca, Dağlık Karabağ bölgesiyle doğal birleşme hakkını da tanımışlardır. Bkz., “Ermenistan'da Bağımsızlığa Adım”, Hürriyet, 24 Ağustos 1990, s. 3.; Milliyetçi Ermenistan Ulusal Hareketi'nin Lideri Levon Ter-Petrosyan'ın devlet başkanlığına seçilmesinin hemen ardından, Ermenistan Parlamentosu bağımsızlık kararı alarak Moskova ile bağlarını koparmıştır. Ermeniler, dış politikasını kendi başına belirlemeyi, Kızıl Ordu'dan bağımsız Ermeni Ordusu kurmayı da kararlaştırmıştır. Bkz., "Bir de Ermenistan Derdi", Hürriyet, 03 Eylül 1990, s. 1, 17.

75 Türkiye ile imzalanmayı bekleyen, beş ayrı konuda hazırlanmış antlaşma taslakları bulunduğunu açıklayan Hasanov, şunları söylemiştir; “Birinci konu, Bakü'de Türkiye'nin bir konsolosluk açması [...] İkinci [...], Nahçıvan sınır kapısı meselesidir. [...] bir köprü yapılmasını, köprü üzerinden demiryolu ve karayolu geçirilmesi [...] 10 km'lik bir demiryolu yapmaya ihtiyacımız var. [...] Türkiye'nin oraya uzanan demiryolu yok. Türkiye'nin de bu demiryolunu yapmasını ve 1991 yılı sonunda, yeni yılı iki devlet rehberlerinin bu köprü üzerinde karşılaşmasını istiyorum. Üçüncü [...], Bakü ile Ankara ve İstanbul arasında direkt telefon bağının sağlanmaSıdır. [...] Dördüncü [...], bir ticaret anlaşmasının imzalanmasıdır. Bizim gemiler Bakü'den çıkıp Volga-Don kanalıyla Karadeniz'e çıkıyor. Gemi taşımacılığında işbirliği yapalım. Beşinci [...], kara taşımacılığıdır. SSCB arazisi içinde Türkiye için yük taşımasını Azerbaycan yapsın istiyoruz.”. Bkz., “Nahçıvan Kapısı 1991'de Açılsın”, Hürriyet, 15 Eylül 1990, s. 16.

76 "Ermenistan Uzlaşmak İstiyor", Hürriyet, 28 Eylül 1990, s. 10.

77 TBMM Tutanak Dergisi, D: 18, YY: 5, C: 53, B: 47, O: 1, 13.12.1990, s. 18, 20 
luk açılması talebi çok geçmeden gelmiş ${ }^{78}$ ve bu talebin gereği yapılmıştır. ${ }^{79}$ Azerbaycan'ın tekliflerinin gündeme alınması, Türkiye'nin bölgesel geleceği açısından doğru görülüştür. Kars'ta buluşan Türk-Azeri heyetleri, Nahçıvan sınır kapısının 15.03.1992'de açlabilmesi için Aras Nehri üzerinde bir köprü yapılmasını kararlaştırmışlardır. ${ }^{80}$ Ermenistan'la da ilişkilerini geliştirmek isteyen Türkiye, Moskova Büyükelçisi Volkan Vural'ın Ermenistan'ı ziyaretiyle başlayan temaslarda, 24 Nisan Ermeni Soykırımı Anama Günü'nün kaldırılmasını istemiştir. Yine, Cumhurbaşkanı Turgut Özal'ın talimatıyla Ermeni meselesini çözmek için çalışmalarına hız veren Hükümet, sözde soykırım günü ilan edilen 24 Nisan'ın yıldönümünde, Ermenistan'a ulaşım ve iletişim alanlarında yatırım önermiştir. Bu sayede, Ermenistan'ın, Türkiye üzerinden dünyaya açılması sağlanmış olacaktı. ${ }^{81}$

Ermenistan'da yönetimde bulunan Levon Ter-Petrosyan'ın gündemi ise çok başkaydı. Moskova'da Gorbaçov'la görüştükten sonra yaptı̆̆g açıklamada, Karabağ ile Azerbaycan'ın Ermenistan'la olan ortak sınırında yaşanan çatışmaları Sovyet Ordusu'nun tertiplediğini iddia etmiştir ${ }^{82}$ Ermenistan'dan kaynaklanan tehdidin artması üzerine, bir kararname yayınlayan Azerbaycan Devlet Başkanı Ayaz Muttalibov da, Azerbaycan Güvenlik Konseyi'ni oluşturmuş ve Ermeni çetecilerin silahtan arındırılmasına kadar operasyonlara devam edile-

78 ANAP İstanbul Milletvekili Bülent Akarcalı'nın konuşmasından. Bkz., TBMM Tutanak Dergisi, D: 18, YY: 5, C: 53, B: 49, O: 1, 15.12.1990, s. 282, 284.; Kültür Bakanı N. Kemal Zeybek, Sovyetler Birliğinde Türkçe konuşulan cumhuriyetlerde, Sultan Sancar Türbesi, Ahmet Yesevi Türbesi ile Aslan Baba Türbesi'nin onarılacağını belirtmiştir. Zeybek, ayrıca, tarihi İpek Yolu üzerinde bir kültür ve turizm projesinin varlığına işaret etmiş, bu konuda ilgili ülkelerle görüşme ve anlaşmalarının bulunduğuna değinmiştir. Bkz. TBMM Tutanak Dergisi, D: 18, YY: 5, C: 53, B: 49, O: 1, 15.12.1990, s. 381-382.

79 ANAP Ankara Milletvekili Hüseyin Barlas Doğu'nun konuşmasından. Bkz., TBMM Tutanak Dergisi, D: 18, YY: 5, C: 61, B: 119, O: 1, 21.05.1991, s. 41, 47.

80 “Azerbaycan'la Sınır Köprüsü Kuruluyor”, Hürriyet, 02 Şubat 1991, s. 3, 12.

81 "Ermenistan'a Dost Eli”, Hürriyet, 24 Nisan 1991, s. 1, 20.; Türkiye'nin, komşularının her biriyle, zaman içerisinde çeşitli ağılıklarda sorunları olduğunu belirten H. Barlas Doğu, "Cumhuriyetimizin kuruluşundan beri [...] böyledir. Bu sorunların hiçbirisini biz yaratmadık. İyi komşuluk ilişkilerinin tesis ve idamesi için, Cumhuriyet dönemi hükümetinin temel politikası oluşturulmuştu. Bu politikayı titizlikle uyguladık [...] Bize dostluk elini uzatan, fazlasıyla karşılık görür; ama, düşmanlığa yelteneni caydırmaya ülke olarak gücümüz, iktidar olarak da azım ve kararımız vardır. İyi komşuluk demek, etrafınızda olup biteni ve aleyhinizde tecelli edeni hesaplayamayacaksınız, [...] pasif ve sessiz kalacaksınız [...] bunu kabul etmiyoruz. [...] kararlı politika sayesindedir ki, etrafımızda düşman halkası yaratılmasının tam tersi, komşularımızın ve yakın çevremizdeki ülkelerle ilişkilerimizin geliştirilmesinde önemli mesafeler alındığını [...] ifade etmek isterim. Kuzey komşumuz Sovyetler Birliği ile ilişkilerimiz, Cumhuriyet tarihindeki en iyi dönemini yaşamaktadır. [... ]" bilgisini paylaşmıştır. Bkz., TBMM Tutanak Dergisi, D: 18, YY: 5, C: 61, B: 119, O: 1, 21.05.1991, s. 41, 44.

82 “Ermenistan, Kremlin'i Suçladı”, Hürriyet, 06 Mayıs 1991, s. 12.; Ter-Petrosyan, Argumenti Facti Dergisi'ne verdiği demeçte de, Kars'ın Ermeni toprağı olduğunu öne sürmüştür. Türkiye'nin, Kars'ta yaşayan Ermenileri kitlesel bir göçe zorladığını ve halen devam eden Karabağ Meselesi'nin de aynı kitlesel göçün bir kez daha tekrarlanmasını önleme mücadelesi olduğunu savunmuştur. Bkz., "Kars Ermeni Toprağıdır", Hürriyet, 13 Mayıs 1991, s. 14. 
SSCB’nin Dağılma Sürecinden BDT’nin Kurulmasına Kadar Geçen Sürede Karabağ Eksenli Olarak, Nahçıvan, Ermenistan ve Azerbaycan Coğrafyasında Yaşanan Gelişmeler ve Türkiye'nin Tutumu (Ekim 1987- Aralık 1991)

ceğini bildirmiştir. ${ }^{83}$ Karabağ Meselesi'nin Moskova tarafından tırmandırıldı̆̆ını iddia eden Ermenistan'ın Moskova Temsilcisi Felix Oganesoviç, Azerbaycan ile diyalog kurmayı istediklerini söylemiştir. ${ }^{84}$

\section{Birliğin Ifflası: Kafkaslarda Bağımsızlık Adımları}

Sovyetler Birliğgi'nin içinde bulunduğu durum, hızlı bir çözülmenin gerçekleşeceğine işaret etmekteydi. Ve Ermenistan, daha Ağustos 1990'da bağımsızlık kararı almakta gecikmemişti. ${ }^{85}$ Durumu değerlendiren Alparslan Türkeş, “[... sınırdaşız; fakat Ermeniler, devamlı Türk düşmanlığına dayanan bir politika içindedirler. [...] bizden daha fazla, Azerbaycan'a karşı düşmanca bir politika takip etmektedirler. Bilhassa Karabağ Meselesi, sömürgecilerin de ustaca kurcalamaları dolayısıyla [...] her gün çatışmalar meydana getirmektedir. Bugün Ermenistan, [...] çevrili durumdadır [...] sıkıntıdan kurtulmak için, Türkiye ile münasebetlerini yumuşatma çabası içerisindedir. [...] 'evvela ticari ve ekonomik münasebetlerimizi geliştirelim; bunun neticesinde siyasi münasebetler de gelişir' şeklinde, bize teklifler ileri sürmektedir. [...] biz [...] siyasi münasebetlerimizi planlarken, Ermenistan'ın Gürcistan'ın durumlarını göz önünde bulundurmak zorundayız ve Ermenistan'ın Azerbaycan'a karşı da düşmanca politikasından vazgeçip, dostluk ve barış politikasına dönmesini istemeliyiz. [...] böyle bir gelişmeyle Ermenistan'ı tanımak, dış politikamıza uygun olabilir." ${ }^{86}$ diyerek, Hükümetin Ermenistan'ı tanımasına yeşil ışık yakmış, destek oluşturmuştur.

Gorbaçov'un, Komünist Partisi Merkez Komitesi'ni lağvetmesinin ardından da, komünizmin en sağlam kalelerinden biri olan Azerbaycan'da, Muttalibov'a karşı gösteriler başlamıştır. Moskova'da, Gorbaçov'a karşı gerçekleştirilmek istenen darbenin başarısızlıkla sonuçlanması üzerine, Azerbaycan Halk Cephesi bir bildiri yayınlayarak; sıkıyönetimin kaldırılmasını, Komünist Parti mal varlığının millileştirilmesini ve başkanlık seçimlerinin ertelenmesini istemiştir. ${ }^{87} 19$ Ağustos tarihindeki darbe girişimi, demokrasiye karşı bir hareketti ve bu hareketin başarı sağlamaması, bütün dünyayı mutlu kılmıştır. Darbecilerin düşündüğünün aksine, Sovyet Cumhuriyetleri'nin bağımsızlık ha-

83 "Ermeni Saldırganlığına Önlem", Hürriyet, 16 Mayıs 1991, s. 12.

84 Bölgede silahlı Ermenilerin bulunduğunu ise yalanlamamıştır. "Ermenistan Temsilcisi Diyalog İstiyor", Hürriyet, 22 Mayıs 1991, s. 14.; Azeri-Ermeni çatışmasından Ermenilerin Moskova'yı mesul tutuğu gibi Azeriler de zaman zaman aynı görüşü paylaşmışlardır. Sovyet Komünist Partisi'nden istifa eden Aliyev, Sovyet yönetiminin Azerilerle Ermenileri birbirine kırdırdığını, Azerbaycan Komünist Partisi'nin de Moskova'nın oyununa alet olduğunu belirterek, "Modaya uymak için istifa etmedim. 20 Ocak'ta halkıma karşı işlenen suç partiden ayrılmama başlıca neden oldu [... 25 kişi bir araya gelse Bakü kumandanı asker gönderiyor ve toplantı dağıtılıyor. Azerbaycan egemenliği böyle olmaz [...]” demiştir. Bkz.,"Moskova, Azeri'yi Ermeni'ye Kırdırmak İstiyor", Hürriyet, 27 Temmuz 1991, s. 12.

85 "Azerbaycan Çatırdıyor", Hürriyet, 26 Ağustos 1991, s. 12.

86 TBMM Tutanak Dergisi, D: 19, YY: 1, C: 1, B: 16, O: 1, 17.12.1991, s. 612. 
reketleri ivme kazanmıştır. ${ }^{88}$ Gorbaçov, yeni birlik anlaşması imzalandığı andan itibaren, birlikten ayrılmak isteyen cumhuriyetlerle bağımsızlık görüşmelerinin başlaması gerektiğini söylemiş, birlik anlaşmasını istemeyen cumhuriyetlere bağımsızlık seçeneğinin tanınması gerektiğine işaret etmiştir. ${ }^{89}$

Gelinen noktayı değerlendiren Hadi Uluengin, şunları kaleme almıştır: "[...] Komünizm defteri kapanmıştır. Bolşevik partisinin, hiçbir şart altında ve hiçbir şekilde yeniden iktidara gelmesi, artık söz konusu değildir. [... Şu anda, iktidar Boris Yeltsin'in elindedir. Mihail Gorbaçov devri bitmiştir. [...] hem hasım hem de müttefik olan bu iki liderin, en azından bir süre için birbirlerine ihtiyaç duyması mümkün gözükmektedir. Yeltsin'in, Gorbaçov'a olan göreceli ihtiyacı, Sovyetler Birliği'ni barış içinde tasfiye sürecinden kaynaklanmaktadır. Gorbaçov ise her halükârda Rusya liderine bağımlıdır. [...] önümüzdeki dönemde Gorbaçov'un 'manevi', Yeltsin'in de 'fiili' önder olacakları bir geçiş dönemi yaşanması muhtemeldir. Ancak, Sovyet önderinin istifa etmesi veya Parlamento tarafından azledilmesi de, halen mevcut varsayımlar arasında düşünülmelidir. [...", 90

Bütün milletvekillerinin hazır bulunduğu, 30 Ağustos 1991 günü gerçekleşen ve televizyondan naklen yayınlanan toplantısında, Azerbaycan Parlamentosu, 1920 yılında Sovyet ordularının müdahalesiyle ortadan kaldırılan Azerbaycan Demokratik Cumhuriyeti'nin yeniden doğuşu yönünde karar almıştır. Bağımsızlığın birlikte, Azerbaycan ayrıca kendi ordusunu kurma kararı da almıştır. Türk Dışişleri Bakanlığı sözcüsü Murat Sungar, karar destek vererek, "[] barışçı müzakereler yoluyla hedefe ulaşılmasını ümit ve temenni ediyoruz" demiştir. ${ }^{91}$ Azerbaycan Milli Merkezi adına 8 Eylül'de Ankara'da yapılan açıklamada, Azerbaycan komünist lideri Muttalibov'un zaman kazanmak ve koltuğunu korumak için zorlama ve sözde bir bağımsızlık ilan ettiği ileri sürülmüş ve Türkiye'nin yürüttüğü politikaların Azerbaycan halkının yararına olduğu bildirilmiştir. ${ }^{92}$ Azerbaycan'ın ardından, Dağlık Karabağ bölgesi de, faaliyetleri

88 Devlet Bakanı ve Başbakan Yardımcısı Erdal İnönü'nün konuşmasından. Bkz., TBMM Tutanak Dergisi, D: 19, YY: 1, C: 1, B: 15, O: 1, 12.12.1991, s. 561.

89 Türk Dışişleri Bakanlığı, Sovyetler Birliğı'nden ayrılarak bağımsızlıklarını ilan edecek olan devletlerin bağımsızlıklarını Türkiye'nin tanıyacağını belirtmiştir. Bkz., "Türkiye, Yeni Devletleri Tanıyacak”/“Sovyetlerde Bağımsızlık Yolu Açıldı”. Hürriyet, 27 Ağustos 1991, s. 14.

90 Hadi Uluengin, "Modern Zamanlar/Büyük Ağustos Devrimi Sonrasında...", Hürriyet, 27 Ağustos 1991, s. 14.

9128 Mayıs 1918 tarihinde Mehmet Emin Resulzade önderliğinde kurulan Azerbaycan Demokratik Cumhuriyeti, 28 Nisan 1920'da Kızıl Ordu müdahalesiyle Sovyet Yönetimi'nin güdümüne girmişti. Bkz., “Azeriler de Bağımsızlık İlan Etti”, Hürriyet, 31 Ağustos 1991, s. 11.

92 Halk Cephesi'nin kurtuluş manifestosu; “1- Münfesih Komünist Partisi'nin uzantısı olan ve milli iradeye dayanmayan Azerbaycan Parlamentosu feshedilmelidir. 2- Azerbaycan Halk Cephesi ağırlıklı ve milli kuruluşların da yer alacağı bir Azerbaycan Milli Şûrası kurulmalı, parlamentonun yetkisi geçici olarak bu kuruluşa devredilmelidir. 3- Bugünkü Azerbaycan Hükümeti derhal istifa etmeli, Azerbaycan'ı gerçek bağımsızlığa götürecek bir Milli Hükümet kurulmalıdır. 4- Hürriyetçi ve çoğulcu demokrasinin temel prensiplerine dayalı modern bir 
SSCB’nin Dağılma Sürecinden BDT’nin Kurulmasına Kadar Geçen Sürede Karabağ Eksenli Olarak, Nahçıvan, Ermenistan ve Azerbaycan Coğrafyasında Yaşanan Gelişmeler ve Türkiye'nin Tutumu (Ekim 1987- Aralık 1991)

askıya alındı̆̆ı halde toplanan parlamentosu marifetiyle, "Cumhuriyet ilanı" kararını oybirliği ile benimsemiştir. Kararın Anayasa'ya aykırı olduğu belirtilmesine rağmen, cumhuriyetin sınırlarının, Azerbaycan'ın Geranboy Bölgesi'ni de kapsaması ${ }^{93}$ dikkat çekici olmuştur. Karabağ'ın bağımsızlık kararına derhal tepki gösteren Azerbaycan, Ermenistan'ın yönlendirici rol üstlendiğini ileri sürmüştür. ${ }^{94}$

Bağımsızlık girişimleri Moskova'da yankı bulmuştur. Yeltsin, darbe girişimi dolayısıyla bir yandan Gorbaçov'u eleştirirken, bir yandan da, "Demokrasi ve özgürlüğü seçen Rusya Devleti, hiçbir zaman bir imparatorluk olamayacaktır, küçük kardeş veya ağabey de olmayacaktır. Diğer cumhuriyetlerle eşit olacaktır." demiş ve tüm cumhuriyetlerin konfederatif bir yapıda egemen devletlerin "Uluslar topluluğu" olarak yan yana yaşamaya devam etmeleri çağrısında bulunmuştur. ${ }^{95}$

Bağımsızlaşma gölgesindeki Kafkaslarda vaziyet gün geçtikçe zorlaşmaktaydı. Karabağ'da Ermenilerle Azeriler arasında ölümcül çatışmalar yaşanmaktaydı. Azerbaycan'da ise Muttalibov'un tek aday olarak katıldığı ve muhalefetin boykot ettiği devlet başkanlığı seçimleri olaylı geçmiştir. Olağanüstü güvenlik önlemlerinin alındığı seçimlerin halkın iradesini yansıtmadığını öne süren Halk Cephesi, vatandaşlardan "seçimlere katılmadım" imzalı kâğıtlar toplamıştır. ${ }^{96}$ Ek olarak, Ermenistan-Nahçıvan sınırında gerginlik meydana gelmiştir. Bir açıklama yapan Ermenistan İçişleri Bakanı Aşot Manuçaryan, gerginlikten kendilerinin sorumlu olduğunu kabul etmiş, durumun karşılıklı düzeltilmesini talep etmiştir. ${ }^{97}$ Halk oylaması sonucu bağımsızlık kararı veren Ermenilerin görüşünü müteakip, 23 Eylül günü toplanan Ermenistan Parlamentosu da, bağımsızlığını ilan ederek Sovyetler Birliği'nden ayrılmıştır. Bu arda, Karabağ Bölgesi'yle ilgili meselenin çözümü için Yeltsin ile Nazarbayev, ilk kez, Azerilerle Ermenileri bir araya getirmiş ve taraflar arasında bir ilke anlaşmasının kabulüne önayak olmuşlardır. ${ }^{98}$

anayasa ile seçim ve partiler kanunu hazırlanmalı, demokrasinin vazgeçilmez unsurlarından olan siyasi partiler kurulmalıdır. 5- Bu yeni düzenlemelerin gerçekleşmesinden sonra her türlü baskı ve terörden uzak, hür seçimlere gidilmelidir.". Bkz., "Azerilerden Ankara'ya Destek", Hürriyet, 07 Eylül 1991, s. 11.

93 “Dağlık Karabağ 'Cumhuriyet' Oldu”, Hürriyet, 03 Eylül 1991, s. 12.

94 "Kafkasya'da Tansiyon Yükseliyor", 04 Eylül 1991, s. 12.; DYP Erzurum Milletvekili İsmail Köse de; Ermenilerin, ani bir kararla, Dağlık Karabağ Bölgesi'nde bağımsız bir Karabağ Devleti için gayri resmi oylama yaptırma girişiminde bulunduklarını belirtmiştir. Bkz., TBMM Tutanak Dergisi, D: 19, YY: 1, C: 1, B: 15, O: 1, 12.12.1991, s. 577, 579. Yeltsin, Gorbaçov için de, "Bu onun son şansı [...] ancak reformlara devam eder ve tüm cumhuriyetlerin bağımsızlığını tanırsa iktidarda kalabilir" demiştir. Bkz., "Rusya, İmparatorluk Olmayacak", Hürriyet, 04 Eylül 1991, s. 12.

96 Askerler üç kişinin ölümüne sebebiyet vermiştir. Muttalibov, büyük gösterilerle protesto edilmiştir. “Azerbaycan'da Kanlı Seçim”, Hürriyet, 09 Eylül 1991, s. 12.

97 "Gerginlikten Sorumluyuz", Hürriyet, 15 Eylül 1991, s. 12.

98 TASS Ajansı'nın haberine göre; Karabağ'ın 'Anayasal iktidar organı' olarak nitelediği bölge- 
Öte taraftan, Başbakan M. Yılmaz, Azerbaycan Başbakanı H. Hasanov ile görüştükten sonra, Azerbaycan'ın 29 Ekim'de ilan etmiş olduğu bağımsızlık kararına Türkiye'nin sıcak baktığını ve ilk Bakanlar Kurulu toplantısında tanınacağını belirtmiştir. ${ }^{99} 9$ Kasım günü toplanan Bakanlar Kurulu, aldığı kararla Azerbaycan'ın bağımsızlığını tanıyan ilk devlet olmuştur. ${ }^{100}$ Bağımsızlık kararının tanınması için harekete geçen Ermenistan da, ABD vatandaşı Dışişleri Bakanı Rafi Hovannisyan aracılığılla, Romanya'nın Moldava'yı, Polonya'nın Beyaz Rusya'yı tanıması gibi, Türkiye'nin de kuzenleri Azerbaycan'ı tanımasını doğal karşıladıklarını, kendilerini de tanımaları için Ankara'ya mektup gönderdiklerini bildirmiş ve Türkiye'nin, yapıcı bir rol oynamasını dilediklerini açıklamiştır. ${ }^{101}$

nin faaliyeti 1989 yılında askıya alınan parlamentosunun yeniden çalışmasına karar verildiğini kaydetmiştir. Anlaşmanın, Azerbaycan'ın Ermenistan tarafına verdiği bir ödün olduğu belirtilmiştir. Buna karşılık Ermenistan da, Dağlık Karabağ Bölgesi'ni Ermenistan toprağı sayan kararını geri almayı kabul ettiği ve Dağlık Karabağ Bölgesi'yle Azerbaycan ve Ermenistan'daki tüm silahlı grupların dağıtılmasını onayladığı belirtilmiştir. Bkz., "Karabağ'da Çözüme Doğru", Hürriyet, 24 Eylül 1991, s. 12.

99 "Azerbaycan'ı Tanıyoruz", Hürriyet, 04 Kasım 1991, s. 17.; Mesut Yılmaz'ın açıklamasına değinen Oktay Ekşi, "Peki ya Bakanlar Kurulu bu görüşe katılmazsa? [...] Bu kurulun hikmet-i vücudu eğer Başbakan tarafından [...] verilmiş kararların altına mühür basmaktan ibaret ise, denecek bir şey yoktur. [...] Dışişleri Bakanlığı 'olupbitti'den hiç de memnun kalmadığını ifade etmektedir. [... daha önceki beyanatlarında bizzat Mesut Yılmaz'ın, 'Azerbaycan olaylarının Türkiye ile SSCB arasındaki ilişkileri olumsuz yönde etkilememesi, Türkiye' nin resmi tutumunu belirleyen en önemli faktörlerden biridir. [|...' dediği bilinmektedir. [...] görüşünü değiştirdiğini, kamuoyuna açıklaması gerekir. Aksi halde [...] Cumhurbaşkanı Turgut Özel gibi dış ilişkilerimizde 'olupbitti'ler yapmaya başladığı izlenimi doğar. |...| Sözlerimizin yanlış anlaşılmaması için bir noktayı belirtmekte yarar görüyoruz: Biz, Sovyetler Birliği'ne mensup iken birbiri ardından bağımsızlıklarını ilan eden cumhuriyetlerle, bunlardan özellikle Türk asıllı olanlarla Türkiye'nin yalın işbirliği kurmasının çok yararlı $[\ldots \mid$ olduğu inancındayız. Çünkü $|\ldots|$ kendi modelimizi, kültürümüzü aktarmayı beceremezsek, başta İran ve Suudi Arabistan olmak üzere pek çok ülkenin etkisine gireceklerinden ve sonunda bu ülkelere benzeyeceğinden endişe ediyoruz. [...] çabaların Moskova'ya rağmen değil, Moskova ile mutabık kalınarak yürütülmesinin hayati derece de önemli olduğuna inanıyoruz." demiştir. Bkz., Oktay Ekşi, “Azerbaycan'ı Tanımak”, Hürriyet, 05 Kasım 1991, s. 1, 21.

Akademik

Bakış

134

Cilt 9 Sayı 17

Kış 2015

100 “Azerbaycan'ı Tanıdık”, Hürriyet, 10 Kasım 1991, s. 15.; Kararı doğru bulmayan F. Çekirge, şu görüş ve tespitleri kaleme almıştır: “Türkiye'nin anlık bir kararla Azerbaycan'ı tanıması, TürkSovyet ilişkilerinin üzerine bir gölge gibi düştü. |...| Oysa Türkiye, Karadeniz İşbirliği Projesi gibi çok daha kapsamlı bir yaklaşımla zaten Azerbaycan'ı tanımıştı. Evet, Azerbaycan'ı tanıyan ilk ülke biz olduk. Bu önemlidir. [... 5 ay önce [...] Bakü'nün Azatlık(Özgürlük) Maydanı'ndaki coşkuyu yaşadım. [...] Azatlık Meydanı'ndan Karadeniz'e doğru akan coşku, Türklük dünyasından çok, bu coğrafyada yaşayan Türklerin dünyayla yeniden entegre oluşunun işaretiydi. Bu işaret Turan ülküsü değil, Karadeniz İşbirliğ̣i Projesi'yle ortaya çıan ve kökleri Osmanlı'nın diplomatik dehasına dayanan çağdaş bir işaretti. [... büyük ülkeler böyle tanıma, tanımama gibi şekle dayalı diplomasiden uzak dururlar. [... Amerika, İngiltere, Fransa, Azerbaycan'ı tanımadılar diye kötü mü oldular? Hayır. Göreceksiniz Azerbaycan'la en büyük işleri o ülkeler yapacaklar. [...] Hasan Mutlucan'dan kahramanlık türküleri çalıp 'Hayda bre Azerbaycan' dedik. Yakında görürüz İran'ın Azerbaycan oyunlarını.". Bkz., Fatih Çekirge, “İşte Böyle Azerbaycan", Hürriyet, 10 Kasım 1991, s. 15.

101 Ermenistan Başkanı Levon Ter-Petrosyan da, bağımsızlık kararına destek bulmak maksadıyla 
SSCB’nin Dağılma Sürecinden BDT’nin Kurulmasına Kadar Geçen Sürede Karabağ Eksenli Olarak, Nahçıvan, Ermenistan ve Azerbaycan Coğrafyasında Yaşanan Gelişmeler ve Türkiye'nin Tutumu (Ekim 1987- Aralık 1991)

\section{Azeri-Ermeni Çatışması Sürerken SSCB'nin Lağvı ve Yeni Birlik (BDT)}

Azerbaycan ve Ermenistan tanınma gayreti içerisindeyken, üst düzey Askeri yetkilileri taşıyan bir helikopter Karabağ'da düşürülmüştür. Bakü'de, yaklaşık 50 bin kişinin katıldığı gösterilerde ise, Devlet Başkanı Muttalibov'un istifası ve Ermeni milislere karşı tedbir alınması istenmiştir. ${ }^{102}$ Olağanüstü toplanan Azerbaycan Parlamentosu ise, nüfusunun çoğunluğunu Ermenilerin oluşturduğu Dağlık Karabağ'ın “özerklik” statüsünü feshetmiş ve başkent Stepanakert'in, tarihi "Hankenti” adını almasına karar vermiştir. Bu gelişme, Muttalibov'a vurulan ağır bir darbe olarak görülmüştür. SSCB Anayasası'na göre içindeki özerk bir bölgeyi feshetme hakkı bulunmakla birlikte, bu kararın birlik parlamentosu tarafından onaylanması gerekiyordu. SSCB Anayasası ise fiilen işlerliğini yitirmiş olduğundan, yasal dayanak noktasında sıkıntı vardı. Hasanov'a bir mesaj gönderen Başbakan S. Demirel, tahriklere geçit verilmemesini, ileride telafisi güç sonuçlar doğuracak karar ve hareketlerden kaçınılmasını istemiştir. ${ }^{103}$

Çatışmanın tırmanmasına engel olmaya çalışan Gorbaçov ise, son andaki girişimleriyle önleyici rol üstlenmiş, Karabağ'ın özerklik statüsünü geri vermiştir. ${ }^{104}$ Bunun üzerine Türkiye, Moskova'ya, "Kafkasya'daki istikrarın korunması için her türlü desteğin sağlanacağı" mesajını vermiştir. ${ }^{105}$

Azeri-Ermeni gerginliği artarken, Başbakan Ayaz Niyazi Muttalibov'un, Halk Cephesi'nin baskıları sonucu, Azerbaycan'da seferberlik ilan etmesi ve cumhuriyet ordusu kurulması yönünde karar alınması üzerine, Kafkasya'da sı-

ABD’ye gitmiştir. Bkz., "Ermenistan, Tanınmak İstiyor", Hürriyet, 13 Kasım 1991, s. 15.; ABD Başkanı George Bush, Sovyetlerde birlik çalışmalarının sürdüğü bir dönemde, cumhuriyetleri tanımayı doğru bulmadıkları gerekçesiyle tanıma kararını geri çevirmiş, Ermenistan'la ilişkilerin daha da güçlendireceklerini belirtmiştir. Bkz., "ABD, Ermenistan'ı Şimdilik Tanımıyor", Hürriyet, 16 Kasım 1991, s. 14.

102 Karabağ'da çatışmaların şiddetlenmesiyle birlikte kontrolü kaybetmek istemeyen Gorbaçov da, iki cumhuriyet arasında tampon bölge oluşturulmasını gündeme getirmiştir. Bkz., “Azerbaycan'ın Sabrı Taşıyor”, Hürriyet, 26 Kasım 1991, s. 12.; Düşen helikopterde, barış görüşmelerine giden Azeri ve Kazak yetkililer bulunmaktaydı. Bkz., "Azeriler Öfkeli”, Hürriyet, 30 Kasim 1991, s. 12.

103 Hürriyet, 28 Kasım 1991, s. 14.

104 Karabağ konusunda Washington, Ermenistan ve Azerbaycan'ı uzlaşmaya çağırırken, İran da, taraflar arasında arabuluculuk yapacağını bildirmiştir. Bkz., "Ermeni-Azeri Çatışmasına Süper Müdahale, Hürriyet, 29 Kasım 1991, s. 14.

105 Demirel'in Hasanov'a gönderdiği mesajda şu görüşlere yer verilmiştir: “1- Türkiye'nin Azerbaycan'ın bağımsızlığını tanıması, Azeri yönetiminin bölgede istikrarı bozucu [...] davranışlarını desteklediği anlamına gelmemelidir. 2- Türkiye, kardeş Azerbaycan'ın ciddi bir devlet anlayışı içinde, bölgesel sorunların diyalog yolu ile [...] çözümlenmesi için aldığı kararları yeniden gözden geçirmesini beklemektedir. 3- [...] Türkiye [...] hakemlik de dâhil, üzerine düşeni yapmaya hazırdır. 4- Türkiye'nin Azerbaycan yönetimine yönelik dostça mesajı, Ermenistan'ın olayları tahrik eden politikasına da destek anlamında değildir. Ermenistan yönetiminin bir süredir, diasporanın etkisinden sıyrılma çabalarına devam etmesi, kalıcı ve adil bir barışın sağlanması için Azerilerle sağlıklı bir diyalog kurması şarttır.”. Bkz., "Türkiye, Sovyetlere Kafkasya İçin Güvence Verdi", Hürriyet, 29 Kasım 1991, s. 14. 
cak çatışma olasılı̆̆ını artırmıştır. Durum karşısında Ermenistan, "Azeri ordusunun kurulmasının, savaş ilanı anlamına geleceğini” belirtmiştir. Azerbaycan Halk Cephesi kaynakları ise, Azeri ordusu kurulmasından sonra Karabağ'daki Ermeni terörüne son vermek üzere harekete geçileceğini açıklamıştır. ${ }^{106}$

Azerbaycan-Ermenistan hattındaki gelişmeler, fiilen sona eren Sovyetler Birliği'ni derinden sarsmaktaydı. Yeni bir birlik anlaşması imzalamak isteyen Moskova yönetimi, çalışmalarına hız verilmiş, "Egemen Devletler Birliği" adını alacak konfederatif yapıda bir birlik yapısı öngörülmüştür. Rusya Federasyonu, Ukrayna ve Beyaz Rusya liderlerinin Minsk'te 9 Aralık günü imzaladıkları yeni bir anlaşmayla, "Bağımsız Devletler Birliği" adında yeni bir birlik kurmaya yönelik çalışmalar başlatılmıştır. ${ }^{107}$ Kazakistan'da yeni bir birlikteliğe imza atılmanın vakti gelmiştir. Eski Sovyet Cumhuriyetleri'nden Rusya, Beyaz Rusya, Ukrayna, Gürcistan, Kazakistan, Moldavya, Azerbaycan, Ermenistan, Özbekistan, Kırgızistan, Türkmenistan ve Tacikistan, 21 Aralık 1991 tarihinde Alma Ata'da bir araya gelerek, 1922 yılında kurulan 69 yıllık SSCB'nin tabutuna son çiviyi çakmışlardır. Hukuki olarak makamının varlığı sona eren Gorbaçov'un da rızasıyla, 31 Aralık gece yarısı tarihe gömülmesi kararlaştırılan Sovyetler Birliği'nin yerini alacak yeni devletler topluluğunun yapısı üç belgeyle, ilke olarak belirlenmiştir. Böylece katılımcı devletler, ekonomik, siyasi ve askeri anlaşmalar ağıyla "eşit statüde" birbirine bağlanmış olacaktı. ${ }^{108}$

Bu arada, Kruşçev'e başdanışmanlık yapmış, yeni Ukrayna Cumhurbaşkanı'nın, 14 Aralık'ta İsviçre'de çıkan Journal de Genevé Gazetesi'nde yayınlanan bir değerlendirmesi dikkat çekici olmuştur. Demiştir ki; "Hıristiyanlık bütün olup bitenlere rağmen hâlâ mühim bir rol oynuyor. Slav birliğinin Müslüman cumhuriyetleri de bünyesine alması, Kazakistan hariç, gerekli değil [...] ittifakta onlara gerek yok. [...] onlar [..] Müslüman'dır. Yarın onlar da istikametlerini bulup, İslâm âlemine yönelirler [...] Kazakların durumu farklı. [...] Kazak nüfusu [...] kendi cumhuriyetlerinde dahi, ancak yüzde 40'dir." 109

106 Seferberlik kararnamesinde, 18 yaşından gün almış gençlerin asker toplama merkezlerine başvurmaları istenmiştir. Sovyet ordusunda görev yapmış subay kadrolarının da seferberliğe dâhil edildiği, böylece yeni Azeri ordusunda komutanlık görevlerini üstelenmeleri temin edilmiş olacaktı. Bkz., "Azerbaycan Seferberlik İlan Etti", Hürriyet, 07 Aralık 1991, s. 12.

107 Devlet Bakanı ve Başbakan Yardımcısı Erdal İnönü'nün konuşmasından. Bkz., TBMM Tutanak Dergisi, D: 19, YY: 1, C: 1, B: 15, O: 1, 12.12.1991, s. 561-562.

108 Yeni topluluğun sınırları içinde yaşayanlara ortak bir vatandaşlık statüsü verilmeyecekti. Bkz., "Moskova'da Doğdu, Alma Ata'da Öldü", Hürriyet, 22 Aralık 1991, s. 14.

109 RP Malatya Milletvekili Oğuzhan Aslıtürk'ün konuşmasından. Bkz., TBMM Tutanak Dergisi, D: 19, YY: 1, C: 2, B: 17, O: 2, 18.12.1991, s. 55, 59.; RP Genel Başkanı/Konya Milletvekili Necmettin Erbakan, Sovyetlerden ayrılan Müslüman devletlerin, oluşturulacak "İslâm Birleşmiş Milletleri"ne üye olmasını istemiştir. Slav birliğine giren ülkelerin bundan vazgeçirilmesini uygun bulduğunu dile getirmiştir. Bkz., TBMM Tutanak Dergisi, D: 19, YY: 1, C: 2, B: 20, O: 1, 25.12.1991, s. 249, 260. 
Alma Ata zirvesi ve kararları Dağlık Karabağ gerilimini yatıştırmamıştır. Ermeni militanların, Şuşa kentine bağlı Kosalar, Kırkıcıhan ve Nebiler köylerine saldırması sonucunda 9 Azeri ile 20 Ermeni hayatlarını kaybetmişlerdir. ${ }^{110}$

Çatışmalar gölgesinde, SSCB'nin sona ermesine değinen Kâmran İnan(ANAP Bitlis Milletvekili), konuyu şu şekilde değerlendirmiş, memnuniyetini dile getirmiştir: "Osmanlı [...] 1914 yılında tasfiye olmuştur. 1917 yılında, [...] Romanof Sülalesi'nin İmparatorluğu ortadan kalkmış [...] arkasından 1921 ve 1922 yıllarında, bugün yıkılmakta bulunan Sovyet Komünist İmparatorluğu gelmiştir. [...] Avusturya-Macaristan [...] Almanların III. Reich [...] ve II. Dünya Savaşı'ndan sonra İngiliz ve Fransız imparatorlukları tasfiye olmuştur. [...] 21 Aralık Cumartesi günü Alma Ata'da yapılan toplantı ile imzalanan Birlik Anlaşması ile, Sovyetler Birliği İmparatorluğu, tarihin tabiatına uygun bir şekilde son bulmuştur ve çok garip bir tesadüftür ki, [...] bugün, Sayın Gorbaçov'un görevi son bulmaktadır. [...] Kuzey'de henüz istikrar yoktur. Kurulan cumhuriyetler $[\ldots]$ yürümesini bile zorlukla yapmaktadırlar. [...] yetişmiş politik kadroları henüz yoktur. [...] serbest ekonomiyi uygulayacak, ileri götürecek yetişmiş kadroları yoktur. [...] Türk Devleti'ne büyük görev düşmektedir. [...] Öğrencilere burslar ihdas etmesinden tutun, ekonomilerinin ayak üstünde durabilecek hale gelmesi, kadroların yetiştirilmesi ki, biz daha Sovyetler Birliği dağılmadan önce İstanbul'da seri toplantılar yaptık. Serbest bankacılık kursları ve diğer alanlarda Doğu Bloğundan gelen insanların eğitimi meselesi Türkiye, bu alanda çok aktif ve yapıcı bir rol oynayabilir. [...|". ${ }^{11}$ Kâmran İnan'ın, ayrıca, "Sovyet cumhuriyetlerinde konsolosluk kurmak kâfi değildir." ikazı da karşılık bulmuştur. Dışişleri Bakanı Hikmet Çetin, derhal harekete geçildiğini ve en kısa zamanda büyükelçilik dönüşümünün başlatılacağını beyan etmiştir. ${ }^{112}$

\section{Sonuç ve Değerlendirme}

SSCB'de Genel Sekreteri Gorbaçov'un, Sovyetler Birliği'nin değişen politikasını ve takip edeceği yolu "Şeffaflık ve Yeniden Yapılandırma" olarak açıklaması, yeni bir takım kıpırdanmalara kapı aralamıştır. Gorbaçov'un Başdanışmanı Ermeni asıllı Abel Aganbegyan, Ermeni isteklerini dile getirirken, ABD'deki Ermeni gruplar, Avrupalılar(Özellikle Fransa ve Almanya) bu istekleri etkili bir biçimde desteklemiş, Gorbaçov'u, baskı yoluyla yönlendirmeye ve sıkıştırmaya çalışılmışlardır. Hız kesmeyen Ermeniler, çevreyi kirletecek bir lastik fabrikasının kuruluşunu protesto amacıyla yoğun gösteriler başlatmışlardır. Bu gösteriler kısa sürede, Karabağ ve Nahçıvan özerk bölgelerinin Ermenistan sınırlarına

110 “Karabağ'da 29 Ölü”, Hürriyet, 28 Ocak 1992, s. 12.; Azerbaycan-Ermenistan gerilimi, geleceğin ciddi meselesi konumundaydı ve bu meseleyi, belki bir ölçüde yumuşatmak, Türkiye'nin kendisi için yaratabileceği çok önemli bir işlev, bir koz olabilirdi. Bkz., SHP İstanbul Milletvekili İsmail Cem'in konuşmasından. TBMM Tutanak Dergisi, D: 19, YY: 1, C: 2, B: 20, O: $1,25.12 .1991$, s. 241, 247.

111 TBMM Tutanak Dergisi, D: 19, YY: 1, C: 2, B: 20, O: 1, 25.12.1991, s. 269-270, 275.

112 TBMM Tutanak Dergisi, D: 19, YY: 1, C: 2, B: 20, O: 1, 25.12.1991, s. 282-283.

Akademik Bakış 137 Cilt 9 Sayı 17 Kış 2015 
dâhil edilmesi eylemlerine dönüşmüştür. Bütün bu gelişmeler, Türkiye açısından; Ermenilerin, Türkiye' den toprak koparmak gayretlerinin bir modeli olarak, Sovyetlerde ete, kemiğe bürünmesi şeklinde kabul görmüştür. Ve Anadolu'nun, Hazar Denizi'ne uzantısı durumunda olan Azerbaycan'ın, bir defa parçalanıp bölünmesi yetmezmiş gibi, tekrar bölünüp parçalanması amaçlanmaktaydı.

Ermeni-Azeri etnik kavgası, Gürcistan ve diğer Sovyet cumhuriyetlerinde de kaygıya yol açmıştır. Sürekli gösteri halini muhafaza eden Ermeniler, Kızıl Ordu birlikleriyle dahi çatışmaktan geri durmamışlardır. Karabağ konusunda çalışmalarını artıran Kremlin Yönetimi, Ermenilerin sürdürdüğü gösterilere boyun eğerek, ani bir kararla, Azerbaycan'a bağlı bu özerk bölgeyi haksızca Moskova'ya bağlamıştır. Karabağ ile birlikte Nahçıvan'ın da devreye sokulması, meselenin Türkiye'den bağımsız gelişemeyeceğini gösteriyordu. Sovyetler Birliği ile Türkiye arasında imzalanmış bulunan Moskova ve Kars antlaşmalarının, Nahçıvan konusunda Türkiye'ye yüklediği sorumluluk, çıkabilecek bir savaşta Türkiye'yi de içine çekecek mahiyetteydi. Bunu göze alamayan Ermeniler, Nahçıvan'ı istemek noktasında çok da ısrarcı davranmamışlardır.

Sovyetler Birliği ile iyi komşuluk ilişkilerini geliştirmek ve komşusunun içişlerine müdahil olmaktan uzak durmak isteyen Türkiye, Sarp Sınır Kapısı ile Nahçıvan Sınır Kapısı'nı açmak suretiyle barış yolunda katkıda bulunmak istemiştir. Ermenistan'da meydana gelen 7.2 şiddetindeki deprem esnasında insani yardım işini de yürütmeye çalışan Türkiye, bu konuda çeşitli engellemeler ve yanlışlıklar dolayısıyla istenilen performansı sağlayamasa da, çatışmacı değil uzlaştırmacı bir politikaya sahip olduğunu göstermek istemiştir. Buna karşın, Ermeniler, Ağrı ve Kars'ı dahi istemekten kendilerini alıkoyamamışlardır.

Nahçıvan-Ermenistan arasında gerçekleşen görüşmelerde kısmi ilerleme sağlanırken, Karabağ konusunda çatışma devam etmiştir. Gerginliği azaltmak ve olayları daha yakından ele almak isteyen Türkiye, Bakü'de bir konsolosluk açmış, Ermenistan'la da diplomatik temas kurmaya çalışmıştır. Ayrıca, Ermenistan'ın Kafkasya'daki tavrını, Kars ve Ağrı'yı istemelerine en sert tepkiyi göstermesi beklenen Milliyetçi Hareket Partisi Genel Başkanı Alparslan Türkeş'in yaptığı bir değerlendirmede, "Siyasi münasebetlerimizi planlarken, Ermenistan'ın Gürcistan'ın durumlarını göz önünde bulundurmak zorundayız ve Ermenistan'ın Azerbaycan'a karşı düşmanca politikasından vazgeçip, dostluk ve barış politikasına dönmesini istemeliyiz. Böyle bir gelişmeyle Ermenistan'ı tanımak, dış politikamıza uygun olabilir." demesi, Türkiye'nin, Ermenilere karşı tarihsel bir düşmanlık beslemediğinin bir göstergesiydi. Ancak Levon Ter-Petrosyan'ın Türkiye'nin girişimlerine gerekli hassasiyetle eğildiği görülmemiştir.

Azeri-Ermeni çatışması, Türkiye'nin de itidal çağırılarına rağmen artmaya devam etmiştir. Hatasından geri dönen ve önleyici rol üstlenen Gorbaçov, Karabağ'ın özerklik statüsünü geri vermiştir. Karabağ'ın özerklik statüsünün 
verilmesinden sonra Türkiye, Azerbaycan yönetiminin bölgedeki gerginliği tırmandırıcı bir politika izlemesi üzerine, Moskova'ya, "Kafkasya'daki istikrarın korunması için her türlü desteğin sağlanacağı" güvencesini vermiştir.

$\mathrm{Bu}$ arada, SSCB'yi oluşturan cumhuriyetlerin katılımıyla gerçekleşen Alma Ata(21.12.1991) zirvesinde, 1922 yılında kurulan 69 yıllık SSCB'nin resmen ve fiilen varlığına son nokta konmuştur. Türkiye, bu kararı memnuniyet verici olarak karşılamış, yeni oluşan durum çerçevesinde tüm cumhuriyetlerle ilişkilerini kültürel, siyasi, iktisadi, sosyal vb. yönlerden geliştirmek gayretinde olmuştur.

Alma Ata zirvesi ve kararları, Dağlık Karabağ geriliminin durmasına etki etmemiştir. Çözüm için, Türkiye'nin, en baştan beri yürüttüğü iyi komşuluk ve dostluk politikalarının, başta Ermeniler olmak üzere tüm taraflarca takip edilmesi, kalıcı bir barışın sağlanması için temel faktör olacaktır.

\section{KAYNAKLAR}

\section{Resmi Arşiv ve Yayınlar}

TBMM Tutanak Dergisi (Aralık 1987-Aralık 1991)

\section{Süreli Yayınlar}

Hürriyet (1987); 22 Ekim, 25 Aralık.

Hürriyet (1988); 12 Mart, 25 Şubat, 27 Şubat, 29 Şubat, 24 Mart, 27 Mart, 30 Mart, 13 Haziran, 15 Haziran, 16 Haziran, 25 Haziran, 07 Temmuz, 09 Temmuz, 11 Temmuz, 13 Temmuz, 15 Temmuz, 18 Temmuz, 19 Temmuz, 24 Temmuz, 23 Eylül, 27 Eylül, 02 Ekim, 25 Kasım.

Hürriyet (1989); 02 Ocak, 16 Ocak, 11 Mayıs, 15 Ağustos, 17 Eylül, 10 Ekim, 06 Kasım. Hürriyet (1990); 06 Ocak, 07 Ocak, 11 Ocak, 15 Ocak, 17 Ocak, 20 Ocak, 21 Ocak, 23 Ocak, 24 Ocak, 25 Ocak, 30 Ocak, 25 Mart, 04 Nisan, 13 Temmuz, 24 Ağustos, 03 Eylül, 15 Eylül, 28 Eylül.

Hürriyet (1991); 02 Şubat, 24 Nisan, 06 Mayıs, 13 Mayıs, 16 Mayıs, 22 Mayıs, 27 Temmuz, 26 Ağustos, 27 Ağustos, 31 Ağustos, 03 Eylül, 04 Eylül, 07 Eylül, 09 Eylül, 15 Eylül, 24 Eylül, 04 Kasım, 13 Kasım, 16 Kasım, 26 Kasım, 28 Kasım, 29 Kasım, 30 Kasım, 07 Aralık, 22 Aralık.

Hürriyet (1992); 28 Ocak.

\section{Kitap ve Makaleler}

ASLAN, Yavuz, "Rus İstilasından Sovyet Ermenistanı'na Erivan(Revan) Vilayeti'nin Demografik Yapısı (1827-1922)", Yeni Türkiye, Ermeni Meselesi Özel Sayısı IV, Yıl: 20, Sayı: 63(Eylül-Aralık 2014), Yeni Türkiye Stratejik Araştırma Merkezi Yay., Ankara, 2014, s. 2610-2626.

Akademik Bakış 139 Cilt 9 Say 17 Kış 2015 
ATTAR, Aygün, Karabağ Sorunu Kapsamında Ermeniler ve Ermeni Siyaseti, AKDTYKAtatürk Araştırma Merkezi Yay., Ankara, 2005.

ÇEKIRGE, Fatih, “Isşte Böyle Azerbaycan”, Hürriyet, 10 Kasım 1991, s. 15.

Dağlık Karabăg Sorunu/Dar Alanda Büyük Oyun, Ed.: Turgut Demirtepe, USAK Avrasya Araştırmaları Merkezi Raporu, No:11-07, 2011.

EKŞİ, Oktay, “Azerbaycan'ı Tanımak”, Hürriyet, 05 Kasım 1991, s. 1, 21.

GÖZELOVA, Nigar, "Rusya İmparatorluğu'nun Dış Politikası ve XIX. Yüzyılın Başlarında İrevan Hanlığı'nda Etnodemografik Durumun Değişmesi”, Yeni Türkiye, Ermeni Meselesi Özel Sayısı IV, Y1l: 20, Sayı: 63(Eylül-Aralık 2014), Yeni Türkiye Stratejik Araştırma Merkezi Yay., Ankara, 2014, s. 2621-2626.

KIZILKAYA, Oktay, "Günümüz Ermenistan Coğrafyasında Türk Nüfusunun Tarihi Süreçteki Durumu", Yeni Türkiye, Ermeni Meselesi Özel Sayısı IV, Yıl: 20, Sayı: 63(Eylül-Aralık 2014), Yeni Türkiye Stratejik Araştırma Merkezi Yay., Ankara, 2014, s. 2599-2609.

IŞYAR, Ö. Göksel, Sovyet-Rus Dış Politikaları ve Karabağ Sorunu, ALFA Yay., İstanbul, 2004, s. 80.

NifTELiYEV, İlgar Vahitoğlu, "1918-1920 Yıllarında Ermenilerin Erivan Bölgesinde Azerbaycan Türklerine Karşı Yaptıkları Soykırım ve Azerbaycan'la İlgili İddiaları", Yeni Türkiye, Ermeni Meselesi Özel Sayısı IV, Yıl: 20, Sayı: 63(Eylül-Aralık 2014), Yeni Türkiye Stratejik Araştırma Merkezi Yay., Ankara, 2014, s. 2627-2639.

TOHiDí, Solmaz Rüstemova, "Birinci Dünya Savaşı Yıllarında Ermeniler Tarafından Azerbaycan'ın Erivan, Zengezur ve Karabağ Eyaletlerinde Müslüman Nüfusunun Soykırımı", Yeni Türkiye, Ermeni Meselesi Özel Sayısı IV, Yıl: 20, Sayı: 63(Eylül-Aralık 2014), Yeni Türkiye Stratejik Araştırma Merkezi Yay., Ankara, 2014, s. 2653-2666.

ULUENGiN, Hadi, "Modern Zamanlar/Büyük Ağustos Devrimi Sonrasında...", Hürriyet, 27 Ağustos 1991, s. 14.

ÜLMEN, Haluk, "Bir Musibet, Bin Nasihatten İyidir", Hürriyet, 27 Şubat 1988, s.1, 14.

\section{Internet Kaynakları}

http://www.aljazeera.com.tr/dosya/ana-hatlariyla-daglik-karabag-sorunu.

http://tr.wikipedia.org/wiki/1988_Spitak_Depremi. 